\title{
Effects of extreme rainfall events on the distribution of selected emerging contaminants in surface and groundwater: The Guadalete River basin (SW, Spain)
}

\author{
Carmen Corada-Fernández ${ }^{\mathrm{a}, *}$, Lucila Candela ${ }^{\mathrm{b}}$, Nivis Torres-Fuentes $^{\mathrm{a}}$, Marina G. Pintado-Herrera ${ }^{\mathrm{a}}$, Maria Paniw ${ }^{\mathrm{c}}$, \\ Eduardo González-Mazo ${ }^{\mathrm{a}}$ \\ a Department of Physical Chemistry, Faculty of Marine and Environmental Sciences, University of Cadiz, Campus of International Excellence of the Sea (CEI-MAR), Rio San \\ Pedro, Puerto Real, 11510 Cadiz, Spain \\ ${ }^{\mathrm{b}}$ Department of Civil and Environmental Engineering-GHS, Technical University of Catalonia-UPC, 08034 Barcelona, Spain \\ c Department of Evol Biol, Population Ecology Group, University of Zürich, Switzerland
}

\section{A R T I C L E IN F O}

\section{Article history:}

Available online $\mathrm{xxx}$

Editor: D. Barcelo

Keywords:

groundwater

surface water

surfactants

pharmaceuticals and personal care products (PPCPs)

emerging contaminants
Received 31 March 2017

Received in revised form 24 May 2017

Accepted 6 June 2017

\begin{abstract}
A B S T R A C T
This study is focused on the Guadalete River basin (SW, Spain), where extreme weather conditions have become common, with and alternation between periods of drought and extreme rainfall events. Combined sewer overflows (CSOs) occur when heavy rainfall events exceed the capacity of the wastewater treatment plants (WWTP), as well as pollution episodes in parts of the basin due to uncontrolled sewage spills and the use of reclaimed water and sludge from the local WWTP. The sampling was carried out along two seasons and three campaigns during dry (March 2007) and extreme rainfall (April and December 2010) in the Guadalete River, alluvial aquifer and Jerez de la Frontera aquifer. Results showed minimum concentrations for synthetic surfactants in groundwater $\left(<37.4 \mu \mathrm{g} \cdot \mathrm{L}^{-1}\right)$ during the first campaign (dry weather conditions), whereas groundwater contaminants increased in December 2010 as the heavy rainfall caused the river to overflow. In surface water, surfactant concentrations showed similar trends to groundwater observations. In addition to surfactants, pharmaceuticals and personal care products (PPCPs) were analyzed in the third campaign, 22 of which were detected in surface waters. Two fragrances (OTNE and galaxolide) and one analgesic/anti-inflammatory (ibuprofen) were the most abundant PPCPs (up to 6540,2748 and $1747 \mathrm{ng} \cdot \mathrm{L}^{-1}$, respectively). Regarding groundwater, most PPCPs were detected in Jerez de la Frontera aquifer, where a synthetic fragrance (OTNE) was predominant (up to $1285 \mathrm{ng} \cdot \mathrm{L}^{-1}$ ).
\end{abstract}

(C) 2017 .

\section{Introduction}

Water quality and its scarcity have become growing concerns over the last century. Consequently, wastewater reuse and its management is currently an important component to guarantee the sustainability of the water cycle (Haruvy, 2006), especially in regions where water scarcity is a permanent issue. One of the main drawbacks of wastewater reuse, however, is the presence of non-regulated, so called "emerging" contaminants. Recent studies have shown that conventional wastewater treatment technologies (sedimentation followed by activated sludge treatment) are not efficient at removing many of these chemicals, so effluent discharges and sludge disposal and/or reuse become the most significant sources of contamination to aquatic and terrestrial settings. Among emerging contaminants, surfactants and personal care products (PCPs) are often the components showing the highest concentrations in wastewater (Kolpin et al., 2002). They comprise a wide subclass of contaminants, covering an-

\footnotetext{
* Corresponding author at: University of Cadiz, Campus of International Excellence of the Sea (CEI·MAR), Río San Pedro s/n, Faculty of Marine and Environmental Sciences, Puerto Real, 11510 Cadiz, Spain.

Email address: carmen.corada@uca.es (C. Corada-Fernández)
}

timicrobials (e.g., triclosan), fragrances (e.g., musk xylene), UV filters (e.g., octocrylene), and surfactants, the main ingredients in cleaning products, shampoos and lotions. All these chemicals may be found not only in the effluents from wastewater treatment plants (WWTPs) but also in the receiving waters. There is, therefore, a growing interest over the last years in monitoring the presence of pharmaceuticals and personal care products (PPCPs) in the environment, mainly in surface water bodies (e.g. rivers and lakes) and in WWTPs (Carballa et al., 2005; Miège et al., 2009; Pedrouzo et al., 2011).

On the other hand, information on the distribution and behavior of surfactants and PPCPs in the unsaturated (vadose) zone (Corada-Fernández et al., 2015), the geological media located between the soil surface and the groundwater level, has been limited to a few areas investigated. Thus, these contaminated soils are a potential source of surface and groundwater pollution by runoff (Oppel et al., 2004) and leaching (Xu et al., 2009). Previous studies have reported the presence of emerging contaminants in European aquifers in Britain (Stuart et al., 2012; Lapworth et al., 2012), France (López et al., 2015) and Italy (Meffe and De Bustamante, 2014). Analysis of these data showed that the most detected compounds were antibiotics and their degradations products (metabolites), except for the nicotine 
and caffeine present. On the other hand, a recent review on the sources, spread and fate of emerging contaminants in European groundwater identified pesticides, endocrine disrupting chemicals, and pharmaceuticals as the most studied compounds (Jurado et al., 2012). In Spain, the presence of PPCPs in aquifers has also been reported (De Bustamante et al., 2010; García-Galán et al., 2010; Estévez et al., 2012; Cabeza et al., 2012; Teijon et al., 2010) mainly focusing in the presence of pharmaceutical active compounds (PhACs). In this sense, the most detected compounds were analgesics, antiinflammatories, diuretics, stimulants and antibiotics (mainly sulfonamides that are also used in veterinary medicine). In this regard, Teijon et al. (2010) analyzed PPCPs in groundwater from a deltaic aquifer (Barcelona, Spain), showing that only 3 out of 18 target compounds were detected at high frequencies: the fragrance galaxolide ( $98 \%$, up to $\left.359 \mathrm{ng} \cdot \mathrm{L}^{-1}\right)$, the antioxidant butylated hydroxytoluene (BHT, $92 \%$, up to $455 \mathrm{ng} \cdot \mathrm{L}^{-1}$ ), and ethylhexyl methoxycinnamate (EHMC, $50 \%$, up to $132 \mathrm{ng} \cdot \mathrm{L}^{-1}$ ), used in sunscreen lotions. Within the same sampling area, Tubau et al. (2010) also investigated the occurrence of synthetic surfactants, including linear alkylbenzene sulfonates (LAS) and alkylphenol polyethoxylate degradation products. In addition, Valdes-Abellan et al. (2013) detected levels up to $219 \mu \mathrm{g} \cdot \mathrm{L}^{-1}$ of LAS in a brackish aquifer from southeastern Spain. However, environmental data on the concentration and distribution of other widely used surfactants, such as alcohol polyethoxylates (AEOs) and alkyl ethoxysulfates (AES), while available for surface waters and sediments (Lara-Martín et al., 2008), are almost non-existent for aquifers.

Due to their wide structural diversity, understanding the different sorption and degradation mechanisms of emerging contaminants in soils are determinant for predicting their mobility and leaching to groundwater. In that sense, some studies have characterized sorption capacity of LAS in laboratory tests under controlled conditions using soil columns irrigated with wastewater (Oliver-Rodríguez et al., 2015; Boluda-Botella et al., 2010; Ou et al., 1999). Transport and degradation in natural soils and oxic and sub-oxic aquifers have been also assessed through field experiments (Ou et al., 1999; Krueger et al., 1998). Additionally, the presence and distribution of emerging pollutants in groundwater may greatly change due to extreme rainstorms and high flood events. This is especially relevant if the drainage system is designed to collect and mix rainwater runoff, domestic sewage, and industrial wastewater. Combined sewer overflow (CSO) events are therefore acknowledged to cause serious water pollution problems (U.S. EPA-833-R-04-001, 2004) although most research on this topic has been focused towards inputs of "conventional" pollutants such as nutrients and suspended solids over surface receiving waters (Gasperi et al., 2010). Emerging contaminants have received less attention (Ellis, 2006; Kasprzyk-Hordern et al., 2009). As an example, Benotti and Brownawell (2007) analyzed the concentrations of several pharmaceuticals in Jamaica Bay in New York (United States) under different weather conditions (dry weather and rain events), establishing a correlation between concentration changes in the receiving waters and their removal in a conventional WWTP. They reported a ten-fold increase in concentration of pharmaceuticals and personal care products (PPCPs) in CSO discharges compared to treated wastewater. Similar results were reported by Buerge et al. (2006) when monitoring caffeine in Swiss urban streams.

This study focuses on the Guadalete basin located Southern Spain (Cadiz, Andalusia), where irrigation with reclaimed water has become a common practice, especially during the summer season. In the area, CSO events are also common during heavy rainfall, leading to an increase in the concentration of organic contaminants in surface water, but their presence in groundwater is scarcely known. In that sense, the main goals of this research were: (a) to investigate the presence of a wide group of PPCPs, with especial emphasis on surfactants, in groundwater from two water bodies (Guadalete and Jerez de la Frontera) and surface waters from Guadalete river (b) to determine their concentration and spatio-temporal distribution, and (c) to assess the effect of extreme rain storm episodes on the river and aquifers in terms of contaminant presence.

\section{Material and methods}

\subsection{Study area}

The study area, the Guadalete River basin (Fig. 1), Jerez de la Frontera (Cadiz, SW Spain), is located on a plain surrounded by small hills (ranging $140 \mathrm{~m}$ ) and open to the Atlantic Ocean at the southern border. Agriculture is the main land use and includes river levees and aquifer outcrops. Some important urban areas, among them Jerez de la Frontera with $>212,000$ inhabitants, are in the study site.

The geology is composed predominantly of tertiary sedimentary materials of detrital origin (blue and white impervious marls; conglomerate/sand layers). Quaternary alluvial. Luvisols and Fluvisols predominate; non-cultivated soils have low permeability and are poorly developed. Water supply in the area for around 60,000 inhabitants (2008 statistical data) and agricultural irrigation is mainly from groundwater exploitation.

Characterized by a moderate Subtropical-Mediterranean climate, the area presents dry summers and mild winters. Proximity of the sea minimizes temperature oscillations during the year, from a monthly average temperature of $10.7^{\circ} \mathrm{C}$ in January to $25.7^{\circ} \mathrm{C}$ in August (State Meteorological Agency, AEMET). Average annual precipitation is $600 \mathrm{~mm}$, although it may present great variability from one year to another. Most of the precipitation takes place during spring and autumn through heavy rain events, whereas droughts are frequent in summer. For the studied period average rainfall was $350 \mathrm{~mm}$ in 2007 (dry year) while values higher than $950 \mathrm{~mm}$ were registered in 2010 (humid year), data provided by the Jerez de la Frontera Meteorological station.

The Guadalete River and tributaries that flow into the Atlantic Ocean through the northern part of the Cadiz Bay, after passing a $157-\mathrm{km}$ stretch across the province of Cadiz, comprise the hydrographic network. Hydrology of the river is characterized by low flows in winter, peak flows in spring/autumn and smaller peaks in summer due to the effect of rainfall events. The catchment hydrological response is dominated by a long dry season and a short wet season; nevertheless, the river streamflow may change quickly from one month to another depending on rainfall. For example, the average height at the Guadalete river flow-gauge station was lower than $2 \mathrm{~m}$ during 2007 (dry year) but up to $8 \mathrm{~m}$ in 2010 after several flooding events (State Meteorological Agency, AEMET) (Plan Hidrológico. Demarcación Hidrográfica del Guadalete-Barbate).

From the hydrogeological standpoint, unconfined aquifer units composed of detrital and alluvial origin constitute the main groundwater resources. Two water bodies, (Plan Hidrologico Guadalete-Barbate) Jerez de la Frontera (code 062.009) and Alluvial Guadalete (code 062.008), outcrop in the area (Fig. 1) is limited by impervious marls. Both aquifers are hydraulically connected through the Salado stream mouth, (Fig. 1, see G27). The Jerez de la Frontera water body, extending over $75 \mathrm{~km}^{2}$ with maximum thickness of $200 \mathrm{~m}$ and an average thickness of $25 \mathrm{~m}$, is composed by calcareous materials, sandy layers, sandstones and silt from the Pliocene and Quaternary ages. Transmissivity ranges between 10 and $100 \mathrm{~m}^{2} /$ day, 


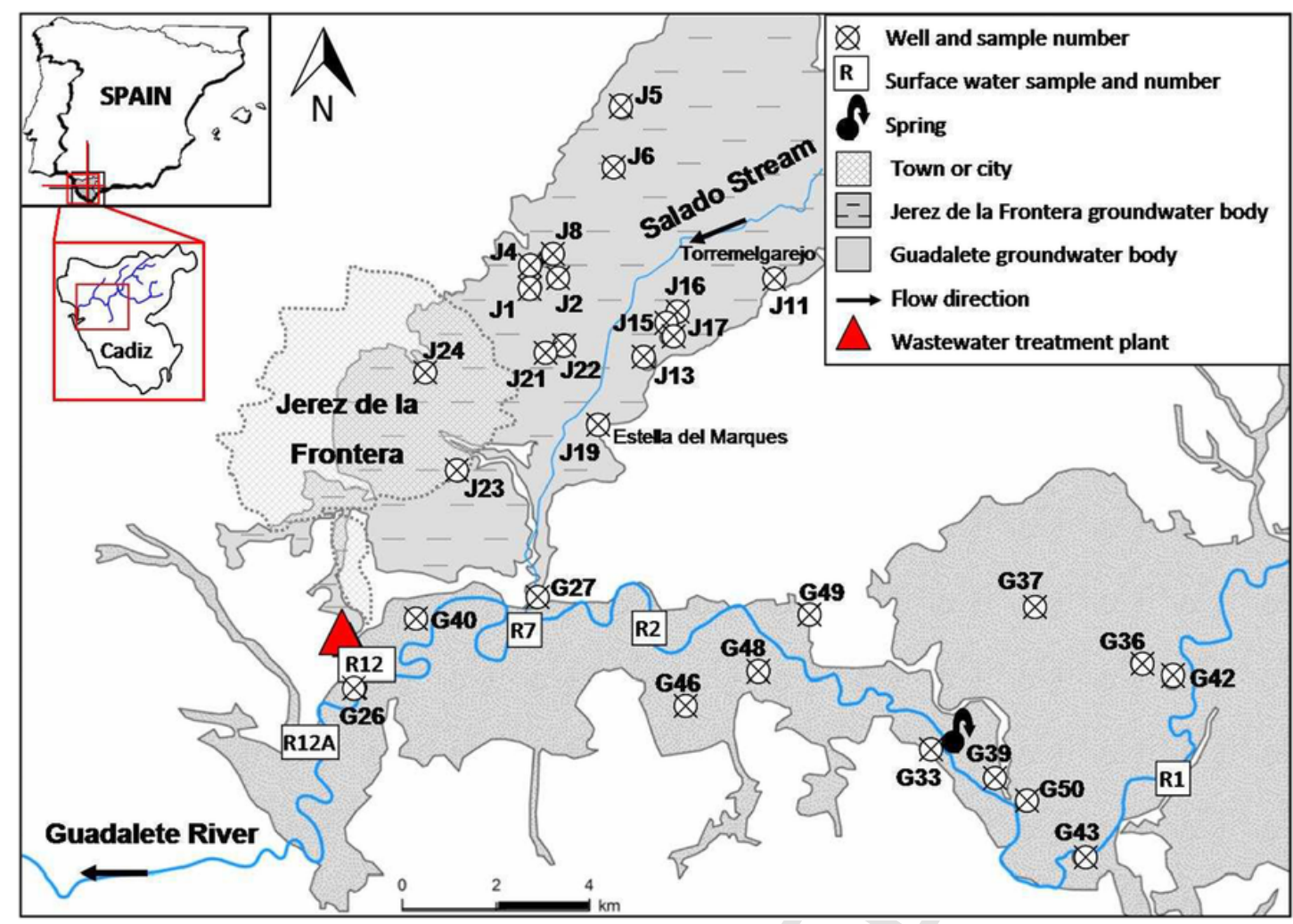

Fig. 1. Map of the Guadalete River basin and study area. Location of sampled points is shown.

being more permeable in the eastern border were most of the exploitation takes place. Groundwater level is generally $<10 \mathrm{~m}$ deep and flow direction is to the Salado stream. Aquifer recharge is from precipitation and irrigation return, while discharge takes place towards the Salado stream and from pumping wells. The Alluvial Guadalete extends over $225 \mathrm{~km}^{2}$ and is composed by quaternary materials and a sandy formation of Pliocene age. The Quaternary aquifer consists of sediments result of the fluvial dynamic evolution of the same river (gravel, sand, silt, and clay) of variable thickness (up to10 m) while Pliocene sands may reach up to $50 \mathrm{~m}$. Permeability values of the sediments range between 5 and $11 \mathrm{~m} /$ day; groundwater levels range between $3 \mathrm{~m}$ in the western part and $>20 \mathrm{~m}$ in the eastern part due to agricultural pumping, with flow direction to the Guadalete river. Aquifer recharge occurs via direct infiltration from the river during floods, precipitation, irrigation, and lateral recharge from Jerez de la Frontera aquifer, through the hydraulically connected area. Discharge occurs from pumping wells and direct drainage to the river and finally to the ocean. According to existing hydrochemical information from sampled points, the groundwater is of calcium bicarbonate type (Perez-Carrera, 2009). The surface water also shows similar hydrochemical characteristics.

Most of the Jerez de la Frontera sewage (approximately 20.000.000 $\mathrm{m}^{3}$ year $^{-1}$ ) is treated at the WWTP and after a secondary treatment discharged into the river at R12 (Fig. 1). However, some other small settlements dump non-treated wastewater to the main watercourse along the Salado stream (Corada-Fernández et al., 2011). Additionally, a fraction of the WWTP effluent $\left(60000-70,000 \mathrm{~m}^{3}\right.$ year $\left.^{-1}\right)$ undergoes tertiary treatment (UV disinfection after filtration) and is applied for the local golf course irrigation and/or discharged into a pond located adjacent to sampling point G26
(Fig. 1). Sludge is composted (4000 tons year ${ }^{-1}$ ) and used by local farmers as fertilizer, covering a surface of up to $10 \mathrm{~km}^{2}$.

\subsection{Sampling campaigns and selected compounds}

To characterize water quality, sampling sites for groundwater and surface water were selected (Fig. 1) for the dry (2007) and humid period (2010). Spatial definition and selection of sites was based on groundwater bodies information, surface and subsurface flow direction and water point constrains.

Sampling included three campaigns: March 2007 (dry season) and during the extreme rainy season (April and December 2010). For groundwater (Fig. 1), a total of 29 samples were collected from Jerez de la Frontera (16 wells and piezometers) and the Alluvial Guadalete (12 wells and piezometers and 1 spring) aquifers. Monitored wells are mainly private wells for agricultural use; wells and piezometers are screened over the entire aquifer thickness or they are partially penetrating wells. For the majority of wells water samples were obtained after pumping; when pumps were not available, a bailer was used. For surface water sampling in Guadalete River, 5 sites were selected (R1, R2, R7, R12, R12A, see Fig. 1). Samples were collected in sterile amber glass bottles $(2.5 \mathrm{~L})$ and immediately stored in an insulated container chilled with ice packs and transported in darkness at $4{ }^{\circ} \mathrm{C}$ to the laboratory; water samples were filtered and analyzed within $48 \mathrm{~h}$. In-situ measurements with a multi-parameter portable recording device (HANNA instruments) included redox potential $\left(\mathrm{E}_{\mathrm{h}}\right), \mathrm{pH}$, temperature (T), electric conductivity (E.C.) and dissolved oxygen (D.O.).

For descriptive statistical analyses of the data gathered in the three sampling campaigns, the R statistical software (R Core Team, 2016) was used. The analyses included classical descriptive and summary statistics, including graphical methods (Q-Q plots and box and 
whisker plots) and a test for significant differences in concentrations between sampling periods (See Suplementary Information). Descriptive statistics do not involve formal distribution hypothesis, however they provide a rapid view of the amount, range and quality of data as presented here. We applied descriptive statistics as an alternative to complement data analysis because sample sizes maybe insufficient for robust statistical analysis.

Regarding compounds, analytes included in this study were selected taking into account the agricultural, urban and industrial activity of the area as well as the EC list of priority substances (The European Parlament and the council of the European Union, 2013) and published literature (Lara-Martín et al., 2008; Corada-Fernández et al., 2011, 2013; Pérez-Carrera et al., 2010). They comprise a group of $>180$ organic pollutants belonging to different compounds categories including different types of surfactants and some of their metabolites, PPCPs (analgesics, antiinflammatories, lipid regulators, antibiotic, endocrine disruptors, UV filters, fragrances, etc.), as well as regulated compounds such as PAHs, PCBs, several classes of pesticides (organochlorine and organophosphorus), triazines, and pyrethroids (Table 1).

\subsection{Analysis of surfactants and other PPCPs in water samples}

The analysis of surfactants and some of their metabolites was carried out during the three sampling campaigns, whereas the rest of PPCPs and endocrine disruptors were measured only in the last campaign (December-2010). Priority contaminants such as polycyclic aromatic hydrocarbons (PAHs), polychlorinated biphenyls (PCBs), and several classes of pesticides were also considered in December 2010 (Table 1).

The analysis of surfactants and metabolites in aqueous samples was carried out according to Lara-Martín et al. (2006). The determination of pharmaceuticals active compounds (PhACs) were performed following the method developed by Baena-Nogueras et al. (2016), whereas the determination of personal care products, endocrine disruptors and priority compounds (PAHs, PCBs, pesticides, triazines and pyrethroids) were performed following the methods developed by Pintado-Herrera et al. (2014) and León et al. (2003). Briefly, synthetic surfactants, their metabolites and PhACs were analyzed by liquid chromatography-mass spectrometry (LC-MS) after solid phase extraction (SPE), whereas endocrine disruptors, PCPs, and priority pollutants were analyzed by gas chromatography-mass spectrometry (GC-MS) after stir bar sorptive extraction (SBSE). More information is available in Supplementary Information.

\section{Results and discussion}

\subsection{The maximum precipitation period of 2010 and hydrologic effects}

For the two natural years (extending from January to December) in which sampling campaigns took place, the rainfall amount at the Jerez de la Frontera Meteorological station (Fig. 2a) accounted for $350 \mathrm{~mm}$ in 2007 (dry year) while values higher than $950 \mathrm{~mm}$ (humid year) were measured in 2010. Except July-September, generally considered dry months, monthly precipitation was always higher in 2010 year. It is important to notice that the amount of precipitation per rainy day shows values $>25 \mathrm{~mm}$ in 2010 with maximum-recorded values of $77 \mathrm{~mm}$, leading to overland flow (Fig. 2b).

The river water height registered at the Jerez de la Frontera weir is jointly plotted with rainfall in Fig. $2 b$. The size of the water level peaks matched the rainfall peaks quite closely, and the presence of
Table 1

List of analyzed compounds.

\begin{tabular}{|c|c|}
\hline Sur & Anionic: LAS, AES. Non Ionic: AEOs, NPEOs. Metabolites \\
\hline al care $p$ & $\begin{array}{l}\text { Insect repellents: IRGAROL and N, N-diethyl-m-toluamide } \\
\text { Benzyl salicylate, ethylhexyl salicylate, homosalate, 4- } \\
\text { methylbenzylidene camphor, octocrylene, } \\
\text { 2-ethylhexyl-4-methoxycinnamate, 2-ethylhexyl } \\
\text { 4-dimethylaminobenzoate, 2-hydroxybenzophenone, } \\
\text { 3-hydroxybenzophenone, 4-hydroxybenzophenone, Oxybet } \\
\text { Mexenone. Polycyclic musks: galaxolide, tonalide, traseoli } \\
\text { and celestolide. Nitro musks: musk xylene, musk ambrette } \\
\text { tibetene, musk ketone and musk moskene. Macrocyclic mı } \\
\text { musk R1, habanolide, exaltenone and muscenone) and othe } \\
\text { (helvetolide, cashmeran and } \\
\text { 1-(1,2,3,4,5,6,7,8-octahydro-2,3,8,8-tetramethyl-2-naphthal } \\
\text { Other frangances: helvetolide, cashmeran and } \\
\text { 1-(1,2,3,4,5,6,7,8-octahydro-2,3,8,8-tetramethyl-2-naphthal } \\
\text { ethanone. }\end{array}$ \\
\hline Endocrine disruptors & $\begin{array}{l}\text { Triclosan, methyl triclosan, nonylphenol, octylphenol, bisph } \\
\text { estrone, } 17-\beta \text { estradiol, and } 17 \alpha \text {-ethynylestradiol. }\end{array}$ \\
\hline $\begin{array}{l}\text { Pharmaceuticals active } \\
\text { compounds (PhACs) }\end{array}$ & $\begin{array}{l}\text { Analgesics/antiinflammatories: ketoprofen, naproxen, ibup } \\
\text { fenoprofen, indomethacin, diclofenac, mefenamic acid, ace } \\
\text { salicylic acid. Phenazone type: phenazone, phenylbutazon } \\
\text { atenolol, metoprolol, timolol, nadolol, pindolol, propanolol } \\
\text { H2/Receptor antagonists: ranitidine, famotidine. Lipid re } \\
\text { clofibric acid, gemfibrozil, fenofibrate, bezafibrate, pravast } \\
\text { atorvastatin. Psychiatric drugs and stimulants: carbamaz } \\
\text { fluoxentine, amitriptiline, caffeine. Diuretics: hydrochlorot } \\
\text { furosemide. Other PhACs: albuterol, glibenclamide, } \\
\text { metotrexate. Penicillins: amoxicillin, penicillin-g, oxacillin } \\
\text { Cephalosporins: cefaclor, cefdinir, ceftiofur, cefadroxil, ce } \\
\text { Tetracyclines: doxycicline, oxytetracycline, chlortetracycli } \\
\text { tetracycline. Amphenicols: tiamulin, chloramphenicol. Ma } \\
\text { erythromycin, roxithromycin, clarithromycin, azithromycin } \\
\text { tylosin. Lincosamides: lincomycin, clindamycin. Sulfonan } \\
\text { sulfamethazine, sulfamethizole, sulfathiazole, sulfadiazine, } \\
\text { sulfamethoxazole, sulfamethoxypyridazine, sulfadimethoxi } \\
\text { sulfisoxazole, sulfaguanidine, sulfanilamide. Quinolones: } f \\
\text { norfloxacin, ofloxacin, ciprofloxacin, enrofloxacin, sparflor } \\
\text { danofloxacin. Aminocoumarin antibiotic: novobiocin, Nit } \\
\text { nitrofurantoin, metronidazole, ornidazole, Other antibiotic } \\
\text { trimethoprim, monensin, ivermectin, rifampicin, chloramph }\end{array}$ \\
\hline & $\begin{array}{l}\text { Acenaphthylene, Acenaphthene, luorene, anthracene, phenar } \\
\text { pyrene, fluoranthene, benzo[ }[a] \text { anthracene, chrysene, } \\
\text { benzo(b)fluoranthene, benzo(k) fluoranthene, benzo(a)pyre } \\
\text { dibenzo(a,h)anthracene, indeno }(1,2,3-\mathrm{c}, \mathrm{d}) \text { pyrene and benzo } \\
\text { perylene. }\end{array}$ \\
\hline PCBs & $\begin{array}{l}\text { PCB28, PCB52, PCB138, PCB153, PCB180, PCB101, triaz } \\
\text { atrazine, prometon, secbumeton, prometryn, terbutryn, prof } \\
\text { terbuthylazine, simetryn, simazinel. }\end{array}$ \\
\hline Pesticides & $\begin{array}{l}\text { Organochlorine Pesticides: lindane, heptachlor, heptachlor } \\
\text { isomer B, } \alpha \text {-endosulfan, } \beta \text {-endosulfan, } \alpha \text {-chlordane, } \gamma \text {-chlor } \\
\text { DDT, o,p'-DDT, p,p'-DDE, endosulfan sulfate, dieldrin, en } \\
\text { methoxychlor, endrin ketone, parathion, ethion, carbophenc } \\
\text { aldrin. Organophosphorus Pesticides: parathion, ethion, } \\
\text { carbophenothion and chlorpyrifos. }\end{array}$ \\
\hline
\end{tabular}


Table 1 (Continued)

\begin{tabular}{ll}
\hline & Anionic: LAS, AES. Non Ionic: AEOs, NPEOs. \\
Surfactants & Metabolites: SPCs, NPs \\
\hline Triazines & Ametryn, atrazine, prometon, secbumeton, prometryn, \\
& terbutryn, propazine, terbuthylazine, simetryn and \\
& simazine. \\
Pyrethroids & Bifenthrin, penothrin (I. II), permethrin (I. II), cyfluthrin (I. \\
& II. III. IV), cypermethrin (I. II. III. IV), deltamethrin (I·II), \\
& fenvalerate (I-II) \\
\hline
\end{tabular}

multiple peaks of different shapes is the consequence of rainfall duration and intensity and the dry/wet antecedent soil-moisture conditions. Basin hydrologic characteristics, climatic and physiographic factors, condition runoff variability. Runoff is highly dependent on precipitation (amount and temporal distribution) and soil moisture conditions. It should be noted that the relations between a precipitation event and produced runoff are not straightforward, the antecedent precipitation and initial soil moisture conditions may be different from one event to another and consequently, basin runoff response. After the December 2010 heavy rainfalls, river flooding and inundations covered the river valley during several weeks, favoring groundwater inflow (river baseflow).

The intensive rainfall period induced aquifer recharge and an increase of groundwater levels (up to $5 \mathrm{~m}$ ) (See supplementary Information, Table S2) in sampled wells. The variation in water levels between nearby wells could be due to differences in hydraulic conductivity and natural heterogeneity of hydrologic media.

\subsection{Presence of synthetic surfactants and PPCPs in the Guadalete River. The effect of extreme events}

A summary frequency of detected surfactants (LAS, AES and AEOs) is presented in Table 2. With regard to surface water, surfactants were detected in all sampling points in the three sampling campaigns. LAS, worldwide the most used surfactant in household and laundry detergents, hand dishwashing liquids, shampoos and personal care products, was the most frequency detected compound with a $94 \%, 93 \%$ and $52 \%$ frequency detection in March, April and December, respectively. By contrast, alcohol polyethoxylates, (AEOs) widely used not only in domestic but also in industrial applications (e.g. detergents, emulsifiers, wettings and dispersing agents, industrial cleaners, etc.), were the least frequently detected surfactants $(3 \%, 1 \%$ and 3\% in March, April and December respectively). Summary statistics for each surfactant in the three campaigns (Table 3 ) shows clear differences in the concentration of the three selected compounds between the sampling campaigns. In addition, test for significant differences confirm these results between sampling periods in surface and groundwater for all compounds with the exception of LAS in surface waters. See supplementary Information, 2.-Statistical Methods.

The effect of surfactants increasing concentrations is clearly reflected in the mean and median statistical parameters.

Fig. 3a shows concentration ranges (box plots) for each surfactant (LAS, AES and AEOs) in surface water. The greatest concentrations were observed for LAS $\left(473 \mu \mathrm{g} \cdot \mathrm{L}^{-1}\right)$ and AES $\left(597 \mu \mathrm{g} \cdot \mathrm{L}^{-1}\right)$, while in the case of AEOs, the concentrations found were one or two orders of magnitude lower (from 1 to $67 \mu \mathrm{g} \cdot \mathrm{L}^{-1}$ ). Several outliers have been identified corresponding to sampling points R7, R12 and R12A that are directly affected by untreated (R7) and treated (R12) urban wastewater discharges. The first one (R7) corresponds to the mouth of the Salado Stream, which collects untreated wastewaters from urban areas and farms surrounding Jerez de la Frontera and the second one
(R12) located very close to the WWTP discharge outlet (Fig. 1). It is important to notice that statistical tests perform more accurately with larger data sets; it is recommended a minimum of at least 8 to 10 independent samples collected before running most statistical tests (EPA 530-R-09-007, 2009). Obtained results should be only taken as an indicator of the system performance.

Concentration of target compounds were lowest $\left(15 \mu \mathrm{g} \cdot \mathrm{L}^{-1}\right.$ for LAS, $5 \mu \mathrm{g} \cdot \mathrm{L}^{-1}$ for AES and AEOs) during the first sampling campaign (March 2007), characterized by a relatively large dry period (precipitation was lower than $50 \mathrm{~mm}$ over the 2 previous months) (Fig. 2a). Fig. 4 shows the average concentrations of LAS, AES and AEOs along the middle and final stretch of the Guadalete River (sampling points: R12A, R12, R7, R2, R1) in March 2007, April and December 2010 . LAS, showed the highest values (15 to $\left.2770 \mu \mathrm{g} \cdot \mathrm{L}^{-1}\right)$, followed by AES, with 5 to $70 \mu \mathrm{g} \cdot \mathrm{L}^{-1}$ and the more hydrophobic AEOs, ranging from 5 to $50 \mu \mathrm{g} \cdot \mathrm{L}^{-1}$. Concentrations of NPEOs, now with restricted use in the EU due to the estrogenic properties of some of their metabolites (NP) (Directive 2013/39/EU, 2013; Jobling et al., 1996), were always $<2 \mu \mathrm{g} \cdot \mathrm{L}^{-1}$. The lowest concentrations were found upstream (samples R1 and R2), in a more pristine area of the river. The highest values were observed in point R7 (Fig. 1) where occasional uncontrolled spills from small rural settlements (e.g., Estella del Marqués) take place (Corada-Fernández et al., 2011). Low concentrations of surfactants were found in R12 and R12A ( $27 \mu \mathrm{g} \cdot \mathrm{L}^{-1}$ for LAS, $12 \mu \mathrm{g} \cdot \mathrm{L}^{-1}$ for AES, $7 \mu \mathrm{g} \cdot \mathrm{L}^{-1}$ for AEOs), in spite of the proximity of the outlet discharge to the Jerez de la Frontera WWTP, which can be attributed to the high efficiency of removal after secondary treatment. Additionally, the existing high temperature $\left(22,5^{\circ} \mathrm{C}\right.$ ) (See Supplementary Information, Table S2) increased degradation rates (León et al., 2004) and removal of surfactants at the WWTP and in the river water, as confirmed by presence of sulfophenyl carboxylic acids (SPCs, the main LAS biodegradation product), at relatively high concentrations $\left(>500 \mu \mathrm{g} \cdot \mathrm{L}^{-1}\right)$ in point R12. Similar SPCs values in aquatic ecosystems affected by urban wastewater discharges have been previously reported [31,32] (León et al., 2003; León et al., 2004).

The April 2010 sampling campaign was carried out after 5 months of heavy rains $(325 \mathrm{~mm}$ and $268 \mathrm{~mm}$ were registered in December 2009 and February 2010 respectively). In addition, heavy rainfall coincided with a CSO event in December 2009 when the river overflowed. The sampling was carried out once the river water height was stabilized at $2.3 \mathrm{~m}$ (Fig. 2b). Concentration of LAS and AES (Fig. 4) were from 24 to $2756 \mu \mathrm{g} \cdot \mathrm{L}^{-1}$ and from 34 to $69 \mu \mathrm{g} \cdot \mathrm{L}^{-1}$, respectively, while AEOs ranged from 1 to $26 \mu \mathrm{g} \cdot \mathrm{L}^{-1}$. Despite the important precipitation amount, concentrations were similar to those found in March 2007; untreated wastewater was not discharged at sampling point R7 that time. The highest SPCs concentrations (up to $1470 \mu \mathrm{g} \cdot \mathrm{L}^{-1}$ ) were found at point R12 once more.

Overall, concentrations found during both the March 2007 and April 2010 sampling campaigns could be regarded as representative of the Guadalete River baseline, provided for the correct functioning of the WWTP while some occasional uncontrolled wastewater discharges through Salado creek could occur. Average values for the compounds reported here are comparable to those found in the estuary of the same river (Lara-Martín et al., 2008) and in sewage-impacted aquatic ecosystems from Europe and United States (Belanger et al., 2006; Petrovic et al., 2002).

By contrast, the third campaign (December 2010) took place during heavy rainfall conditions with a river water height of approximately $4.5 \mathrm{~m}$ (Fig. 2b), causing important overland flow. In this campaign, the highest concentrations of LAS (215 to $\left.3996 \mu \mathrm{g} \cdot \mathrm{L}^{-1}\right)$, AES $\left(63\right.$ to $1609 \mu \mathrm{g} \cdot \mathrm{L}^{-1}$,) and AEOs $\left(23\right.$ to $\left.141 \mu \mathrm{g} \cdot \mathrm{L}^{-} 1\right)$ were found 
a)

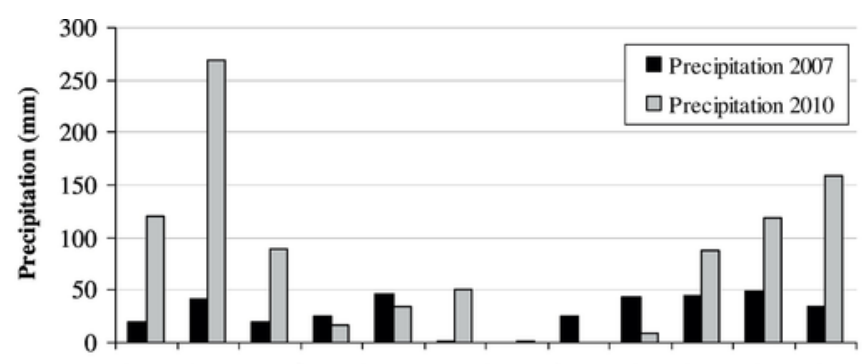

b)
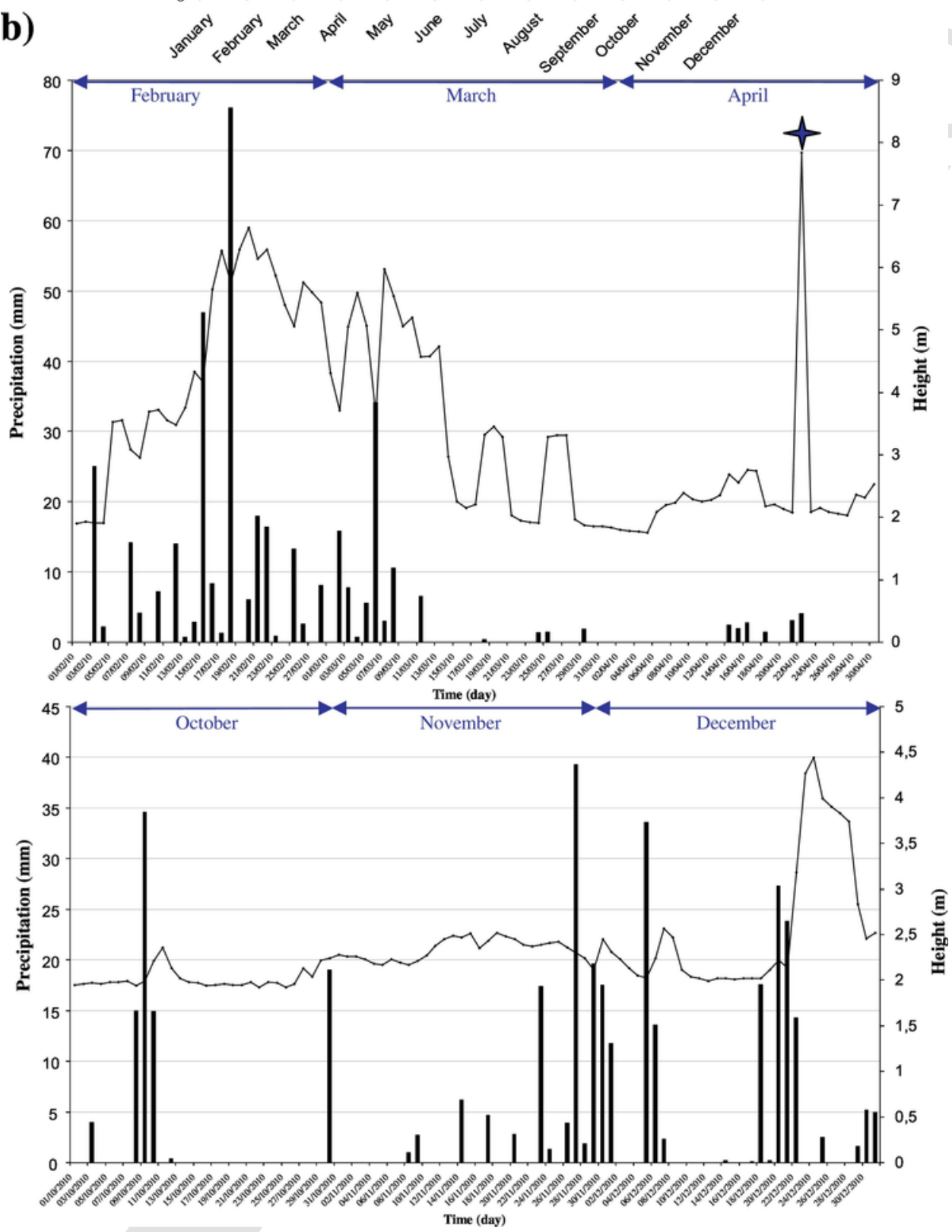

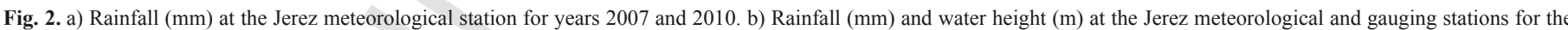
2010 sampling periods. Data show refers to a natural year (January to December). Anomalous data.

in sampling points R12 and R7. Similar LAS concentrations have been reported in very heavily polluted areas subjected to untreated urban wastewater discharges, where LAS occasionally exceeded $1500 \mu \mathrm{g} \cdot \mathrm{L}^{-1}$ (González-Mazo et al., 1998). AES and AEO values are also certainly among the highest ever reported in the literature, which are usually between 0.1 and $50 \mu \mathrm{g} \cdot \mathrm{L}^{-1}$ (Belanger et al., 2006;
Petrovic et al., 2002; Dunphy et al., 2001; Eadsforth et al., 2006; Fendinger et al., 1995; Lara-Martín et al., 2005; Sanderson et al., 2006).

Such high surfactant levels are directly related to CSO events and overland flow generation which may contribute to contaminant losses 
Table 2

Frequency of detected surfactants (LAS, AES and AEOs) in groundwater and surface water. Spring data are included as groundwater data set.

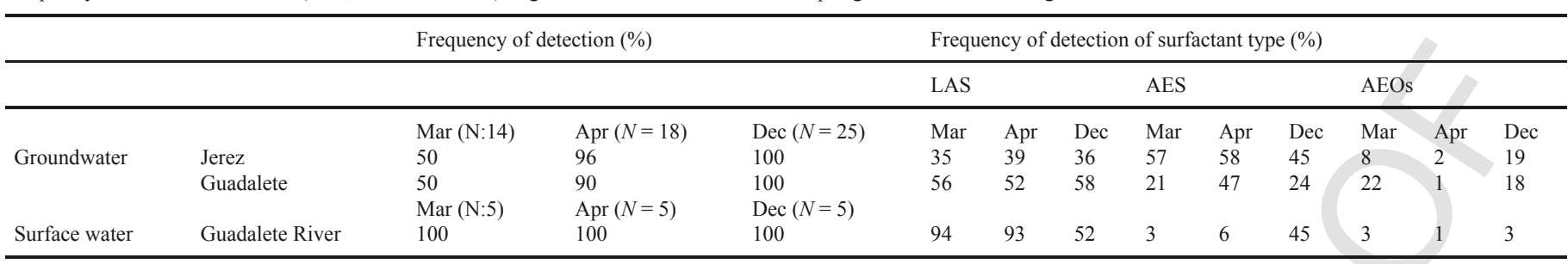

Table 3

Main statistics for surfactants, in groundwater and surface water. Whole data set $(\mathrm{N}=$ number of samples)

\begin{tabular}{|c|c|c|c|c|c|c|c|}
\hline Sampling & Compound & $\mathrm{N}$ & $\begin{array}{l}\text { Minimum } \\
\left(\mu \mathrm{g} \cdot \mathrm{L}^{-1}\right)\end{array}$ & $\begin{array}{l}\text { Maximum } \\
\left(\mu \mathrm{g} \cdot \mathrm{L}^{-1}\right)\end{array}$ & $\begin{array}{l}\text { Mean } \\
\left(\mu g \cdot L^{-1}\right)\end{array}$ & $\begin{array}{l}\text { Median } \\
\left(\mu \mathrm{g} \cdot \mathrm{L}^{-1}\right)\end{array}$ & $\begin{array}{l}\text { SD } \\
\left(\mu \mathrm{g} \cdot \mathrm{L}^{-1}\right.\end{array}$ \\
\hline \multicolumn{8}{|c|}{ Groundwater } \\
\hline & LAS & 14 & 0.0 & 15.5 & 4.8 & 1 & 5.6 \\
\hline \multirow{3}{*}{$\begin{array}{c}\text { March } \\
2007\end{array}$} & AES & 14 & 0.0 & 37.4 & 5.8 & 0.0 & 10.9 \\
\hline & AEOs & 14 & 0.0 & 6.0 & 1.4 & 0.0 & 2.3 \\
\hline & LAS & 18 & 0.0 & 362.6 & 50.7 & 13.4 & 90.0 \\
\hline \multirow[t]{3}{*}{ April 2010} & AES & 18 & 13.8 & 178.5 & 57.4 & 41.2 & 40.6 \\
\hline & AEOs & 18 & 0.0 & 5.7 & 2.1 & 1.4 & 1.6 \\
\hline & LAS & 25 & 85.6 & 795.4 & 162.6 & 115.0 & 152.1 \\
\hline \multirow{2}{*}{$\begin{array}{l}\text { December } \\
2010\end{array}$} & AES & 25 & 9.6 & 665.0 & 112.1 & 25.1 & 177.8 \\
\hline & AEOs & 25 & 19.4 & 139.3 & 61.3 & 56.8 & 27.9 \\
\hline \multicolumn{8}{|c|}{ Surface water } \\
\hline & LAS & 5 & 15.0 & 2766.0 & 573.0 & 27.0 & 1225.0 \\
\hline \multirow{3}{*}{$\begin{array}{c}\text { March } \\
2007\end{array}$} & AES & 5 & 5.0 & 72.0 & 19.8 & 5.0 & 29.0 \\
\hline & AEOs & 5 & 5.0 & 49.0 & 16.0 & 8.0 & 19.0 \\
\hline & LAS & 5 & 24.2 & 2756.1 & 721.06 & 228.8 & 1145.6 \\
\hline \multirow[t]{3}{*}{ April 2010} & AES & 5 & 34.4 & 69.3 & 48.6 & 46.0 & 13.2 \\
\hline & AEOs & 5 & 0.5 & 25.7 & 8.8 & 6.7 & 9.8 \\
\hline & LAS & 5 & 215.4 & 3996.1 & 1027.9 & 239.2 & 1662.8 \\
\hline \multirow{2}{*}{$\begin{array}{l}\text { December } \\
2010\end{array}$} & AES & 5 & 63.2 & 1608.7 & 894.5 & 872.5 & 608.3 \\
\hline & AEOs & 5 & 23.4 & 140.8 & 65.1 & 55.3 & 45.5 \\
\hline
\end{tabular}

from landscape via surface runoff (suspended sediment or dissolved phase). CSO is a main source of emerging contaminants in surface waters (Ellis, 2006; Buerge et al., 2006), and consequently of untreated wastewater discharge into the river. These results are in agree- ment with some recent studies that analyzed the variation of emerging contaminants (pharmaceuticals and PCPs) depending on the precipitation amount (Benotti and Brownawell, 2007; Buerge et al., 2006; Del Río et al., 2013). The impact of CSO events in LAS and AES concentration in surface sediments in the estuary of the Guadalete River was also reported by Lara-Martín et al. (2010) during 2001 and 2002 , focusing on the correlation between seasonal changes in surface sediments and monthly differences in temperature and precipitation, achieving similar conclusions than in the present study.

Additionally, with an influent flow much greater than plant capacity, a decrease of the removal efficiency of the wastewater treatment plant can be expected. Temperature was also lower during this sampling campaign (between 14 and $16^{\circ} \mathrm{C}$ ) (See Supplementary Information, Table S2), slowing degradation processes.

Results for the PPCPs and regulated compound presence in the Guadalete River for December 2010 are shown in Table 4a and b, showing that 24 out of $>180$ target compounds were found. Regarding PCPs and priority pollutants (Table 4a), an antimicrobial and endocrine disruptor (triclosan), pesticides (lindane and terbuthylazine) and UV filters (EHMC and benzophenone 3) were found at concentrations lower than $150 \mathrm{ng} \cdot \mathrm{L}^{-1}$; phenanthrene (PAH) and octocrylene (UV filter) were under the quantification limit $(<$ LOQ). Fragrances, OTNE and galaxolide (up to 6540 and $2748 \mathrm{ng} \cdot \mathrm{L}^{-1}$, respectively), followed by tonalide (up to $259 \mathrm{ng} \cdot \mathrm{L}^{-1}$ ) were found with greater concentrations. OTNE and galaxolide are the two most used synthetic fragrances at the EU (Bester et al., 2008) and they are effectively removed (between 70 and 90\%) in WWTPs according to Carballa et al. (2005). However, OTNE was reported to be not readily biodegradable in OECD tests and the concentrations found in the river are comparable to those found in raw wastewater in US (3600 $\mathrm{ng} \cdot \mathrm{L}^{-1}$ ) and EU (9000 $\left.\mathrm{ng} \cdot \mathrm{L}^{-1}\right)$. According to a recent study

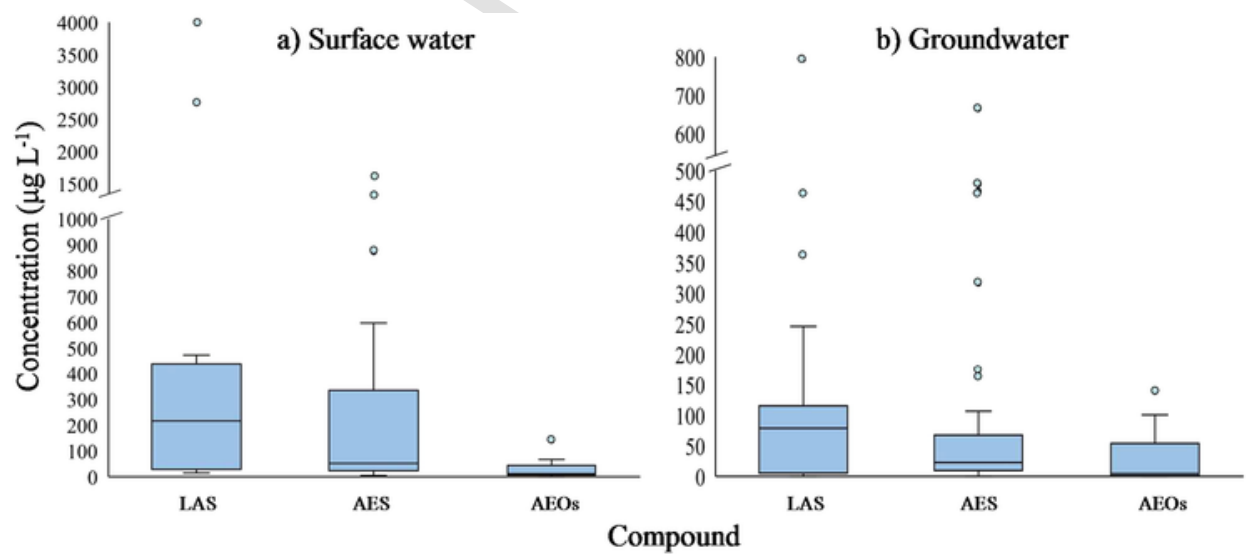

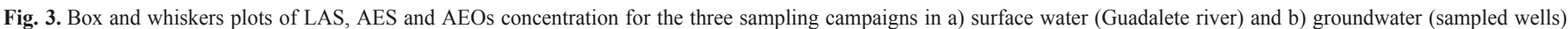
Median of data set is the horizontal line within the box limits (Q1 and Q3). Several outliers are identified. 

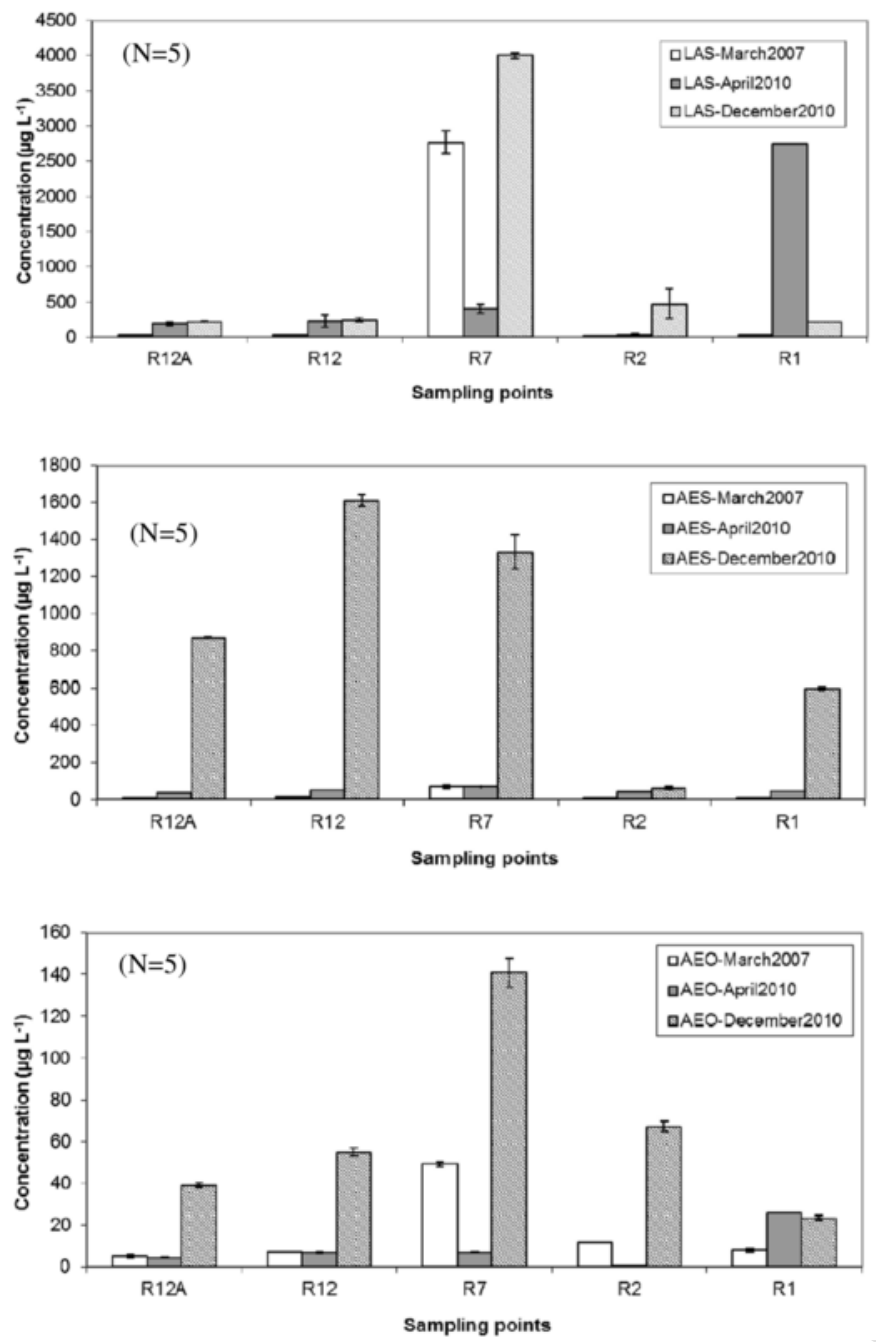

Fig. 4. Surfactants concentration $\left(\mu \mathrm{g} \cdot \mathrm{L}^{-1}\right)$ (LAS, AES and AEOs) in surface water (Guadalete River) for March 2007, April 2010 and December 2010. (Points description: $\mathrm{R} 12 \mathrm{~A} \& \mathrm{R} 12=\mathrm{WWTP}$ effluent; R7 = not treated areas; R2 \& R1 = river upstream). $\mathrm{N}=$ number of samples per sampling campaign.

carried out by Del Río et al. (2013), these compounds may also accumulate in biofilms in sewer and particulate matter during dry periods and later undergo significant mobilization in wet weather associated with the washout of pipes (Del Río et al., 2013). Regarding PhACs (Table 4b), the higher concentrations were found in sampling point R7 (Fig. 1) heavily influenced by untreated (e.g., Salado Stream) wastewater. Three analgesics/anti-inflammatories (ibuprofen, acetaminophen and naproxen) showed the highest concentrations (up to 1747,406 and $289 \mathrm{ng} \cdot \mathrm{L}^{-1}$ ), followed by an stimulant (caffeine), a lipid regulator (gemfibrozil) and a diuretic (hydrochlorothiazide) with 233,200 and $126 \mathrm{ng} \cdot \mathrm{L}^{-1}$ respectively.

\subsection{The effect of extreme events on the presence of surfactants and other PPCPs in groundwater}

According to results (See Supplementary Information, Table S2), groundwater samples present low electric conductivity, neutral $\mathrm{pH}$ and oxidizing conditions (except J15 also showing basic pH). Frequency of detected surfactants (LAS, AES and AEOs) is presented in Table 2. With regard to groundwater, the frequency of all surfactants increased from 50\% in March 2007 to $100 \%$ in December 2010, with a widespread contamination of water bodies. A summary of surfactant concentrations for the three campaigns can be found in Table 3 . The graphical results, boxplot of Fig. 3b, show concentration ranges (Q1 and Q quartiles) for each surfactant (LAS, AES and AEOs) in groundwater. Greatest concentrations (including median) are for LAS followed by AES and AEOs $\left(246,164\right.$ and $100 \mu \mathrm{g} \cdot \mathrm{L}^{-1}$ respectively). Several outliers, extreme local concentration values, are also identified. The effect of surfactants increasing concentration along time (sampling campaigns) is clearly reflected in the statistical parameters (especially mean and median) for the three selected compounds. The standard deviation (SD) also reflects the important differences of concentration in sampled points, being for LAS and AES greater than the mean in 2010 campaigns. Tests for significant differences in concentrations confirm these results (See supplementary Information, 2.-Statistical Methods).

Fig. 5 shows the concentration and distribution of surfactants in the Alluvial Guadalete and Jerez de la Frontera water bodies for the three sampling campaigns (March 2007, April and December 2010). In March 2007 (dry period), the presence of surfactants in both aquifers was relatively uniform in the 29 sampled wells (around $10 \mu \mathrm{g} \cdot \mathrm{L}^{-1}$ ) and the ionic surfactants LAS, AES and AEO showed the lowest concentration which could represent or be considered as "the current/anthropic background concentration". Some local maximum values were observed in the western part, where significant impacts from human activities are expected due to the presence of the WWTP outlet, as well as higher density of irrigated crops (including golf courses). Additionally, these chemicals tend to concentrate in wells J-19, G-27 as groundwater moves down flow direction (Fig. 1, Fig. 5a-c). LAS and AES value ranged from 0.5 to $15.5 \mu \mathrm{g} \cdot \mathrm{L}^{-1}$ and from 1.5 to $37.4 \mu \mathrm{g} \cdot \mathrm{L}^{-1}$, respectively, while values for AEOs were between $<1$ and $6 \mu \mathrm{g} \cdot \mathrm{L}^{-1}$. NPEOs -not shown in Fig. 5- were only found in two sampling points (J6 and J19, Fig. 1) at concentration below $0.5 \mu \mathrm{g} \cdot \mathrm{L}^{-1}$. Surfactant presence may be the result of agricultural irrigation with river water mixed with reclaimed water from the Jerez de la Frontera WWTP, as well as sludge application on soils after anaerobic digestion. Additionally, some surfactants such as AEOs and NPEOs are commonly applied in pesticide formulation to increase wettability. Presence of some pesticides (chlorfenvinphos, chlorpyriphos, prometryn, and triazines) jointly with nitrate concentrations up to $65.8 \mathrm{mg} \cdot \mathrm{L}^{-1}$ in both groundwater bodies supports our conclusions (Perez-Carrera, 2009).

For the two extreme hydrologic episodes (April and December 2010), an increasing trend of surfactant concentrations was observed (Fig. 5d-i) reaching its maximum in December. This effect is clearly observed in the Q-Q plot (Fig. 6), where after a flat trend, a significant slope change identifies two groups of points. The lowest values here correspond to "background" values whereas the highest values correspond to the 2010 samples. In April (Fig. 5d-f), highest LAS, AES and AEOs concentrations were 362,178 and $6 \mu \mathrm{g} \cdot \mathrm{L}^{-1}$, respectively. Similar maximum values have been reported for an inland brackish aquifer in SE Spain (Valdes-Abellan et al., 2013) On the other hand, NPEO was found below $1 \mu \mathrm{g} \mathrm{L}^{-1}$ in wells J-2 and J-19. Maximum surfactants values were in farmland wells, G-43 and J-16. In December 2010, after the extreme rainfall events, concentrations of up to $795 \mu \mathrm{g} \mathrm{L}^{-1}$ for LAS and $665 \mu \mathrm{g} \mathrm{L}^{-1}$ for AES were found; the highest values $\left(>500 \mu \mathrm{g} \mathrm{L}^{-1}\right)$ in wells $\mathrm{J}-16, \mathrm{~J}-19, \mathrm{~J}-23$, and G-27 (Fig. 1; Fig. 5g-i), and in G-39 $\left(478 \mu \mathrm{g} \mathrm{L}^{-1}\right)$ and G-42 $\left(465 \mu \mathrm{g} \mathrm{L}^{-1}\right)$ (Fig. 1) all associated with farming. Non-ionic surfactants, commonly used in industrial detergents formulations and other more specific applications (e.g., wetting agents, dispersers, emulsifiers), were detected in all samples at low concentrations (between 25 and 
Table 4

Concentration $\left(\mathrm{ng} \cdot \mathrm{L}^{-1}\right)$ of detected PCPs and pesticides in groundwater and surface water in December 2010. - Not detected compound.

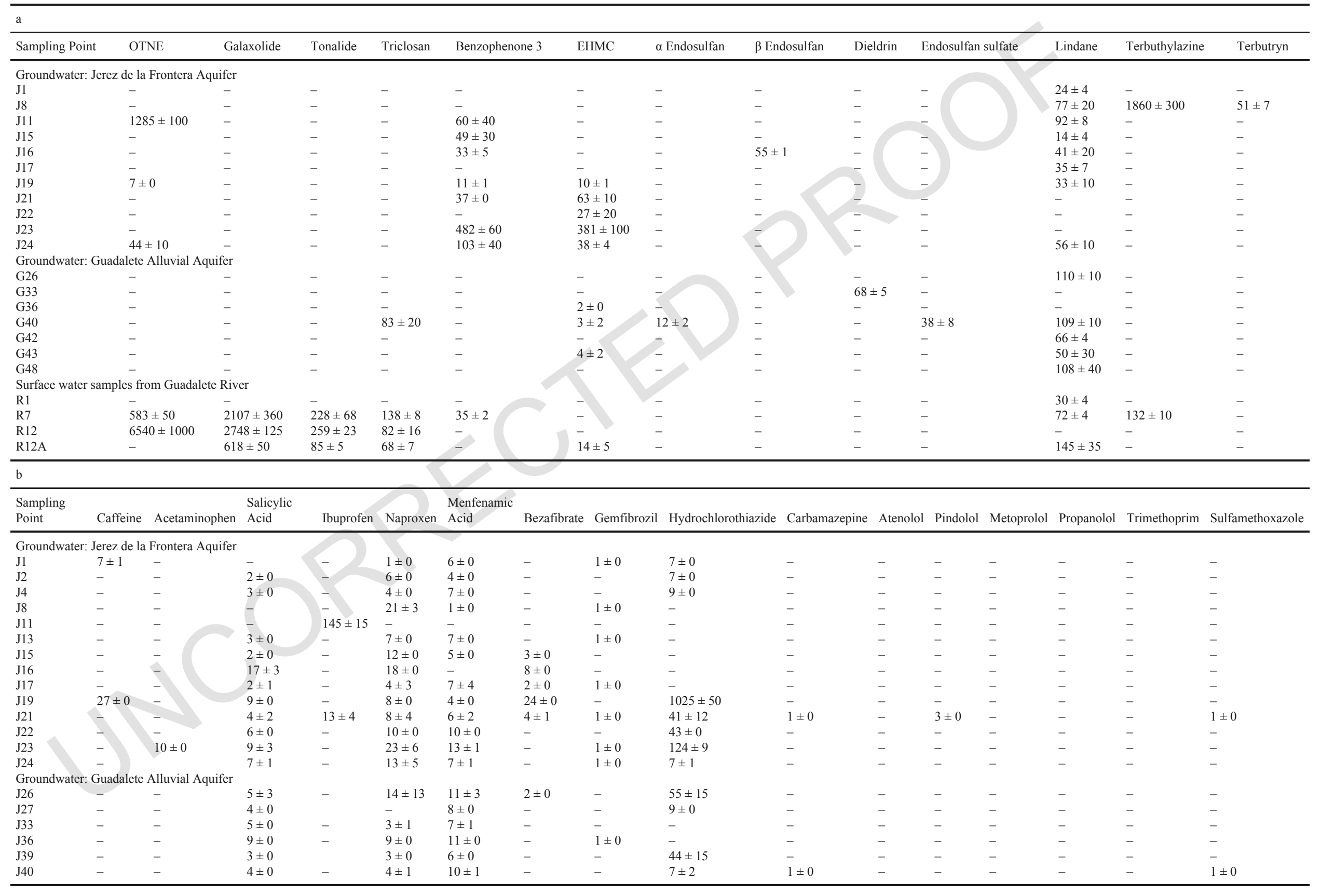


Table 4 (Continued)

\begin{tabular}{|c|c|c|c|c|c|c|c|c|c|c|c|c|c|c|c|c|}
\hline \multicolumn{17}{|l|}{ b } \\
\hline $\begin{array}{l}\text { Sampling } \\
\text { Point }\end{array}$ & Caffeine & Acetaminophen & $\begin{array}{l}\text { Salicylic } \\
\text { Acid }\end{array}$ & Ibuprofen & Naproxen & $\begin{array}{l}\text { Menfenamic } \\
\text { Acid }\end{array}$ & Bezafibrate & Gemfibrozil & Hydrochlorothiazide & Carbamazepine & Atenolol & Pindolol & Metoprolol & Propanolol & Trimethoprim & Sulfamethoxazole \\
\hline $\mathrm{J} 42$ & - & - & $5 \pm 1$ & - & $7 \pm 1$ & $7 \pm 2$ & - & - & $3 \pm 1$ & - & - & $3 \pm 0$ & - & - & - & - \\
\hline $\mathrm{J} 43$ & - & - & $3 \pm 0$ & - & $1 \pm 0$ & $7 \pm 0$ & - & $1 \pm 0$ & $10 \pm 0$ & - & - & - & - & - & - & - \\
\hline $\mathrm{J} 48$ & - & - & $2 \pm 0$ & - & $6 \pm 1$ & $5 \pm 0$ & $1 \pm 0$ & - & - & - & $3 \pm 1$ & - & - & - & - & - \\
\hline J49 & - & - & $3 \pm 1$ & & $5 \pm 1$ & $8 \pm 1$ & - & - & - & - & - & - & - & - & - & - \\
\hline Spring & - & - & $4 \pm 0$ & & $5 \pm 1$ & $5 \pm 2$ & $1 \pm 1$ & $1 \pm 0$ & $42 \pm 15$ & - & - & - & - & - & - & - \\
\hline \multicolumn{17}{|c|}{ Surface water samples from Guadalete River } \\
\hline R1 & $19 \pm 2$ & $19 \pm 4$ & $6 \pm 0$ & - & $27 \pm 3$ & $13 \pm 1$ & $2 \pm 0$ & $18 \pm 1$ & $21 \pm 11$ & $1 \pm 0$ & $3 \pm 1$ & $2 \pm 0$ & $6 \pm 0$ & - & - & - \\
\hline R2 & - & $6 \pm 2$ & - & - & $34 \pm 7$ & $9 \pm 1$ & $3 \pm 0$ & $22 \pm 4$ & $13 \pm 2$ & - & - & - & - & - & - & - \\
\hline R7 & $233 \pm 67$ & $406 \pm 9$ & $13 \pm 4$ & $1747 \pm 43$ & $289 \pm 14$ & $16 \pm 1$ & $11 \pm 0$ & $200 \pm 26$ & $126 \pm 22$ & $1 \pm 0$ & $16 \pm 11$ & _- & _- & $1 \pm 0$ & $3 \pm 0$ & $3 \pm 0$ \\
\hline R12 & $26 \pm 3$ & - & $5 \pm 1$ & - & $31 \pm 3$ & $9 \pm 0$ & $8 \pm 1$ & $79 \pm 6$ & $63 \pm 1$ & $2 \pm 0$ & $21 \pm 1$ & - & - & $1 \pm 0$ & $2 \pm 0$ & $1 \pm 0$ \\
\hline
\end{tabular}




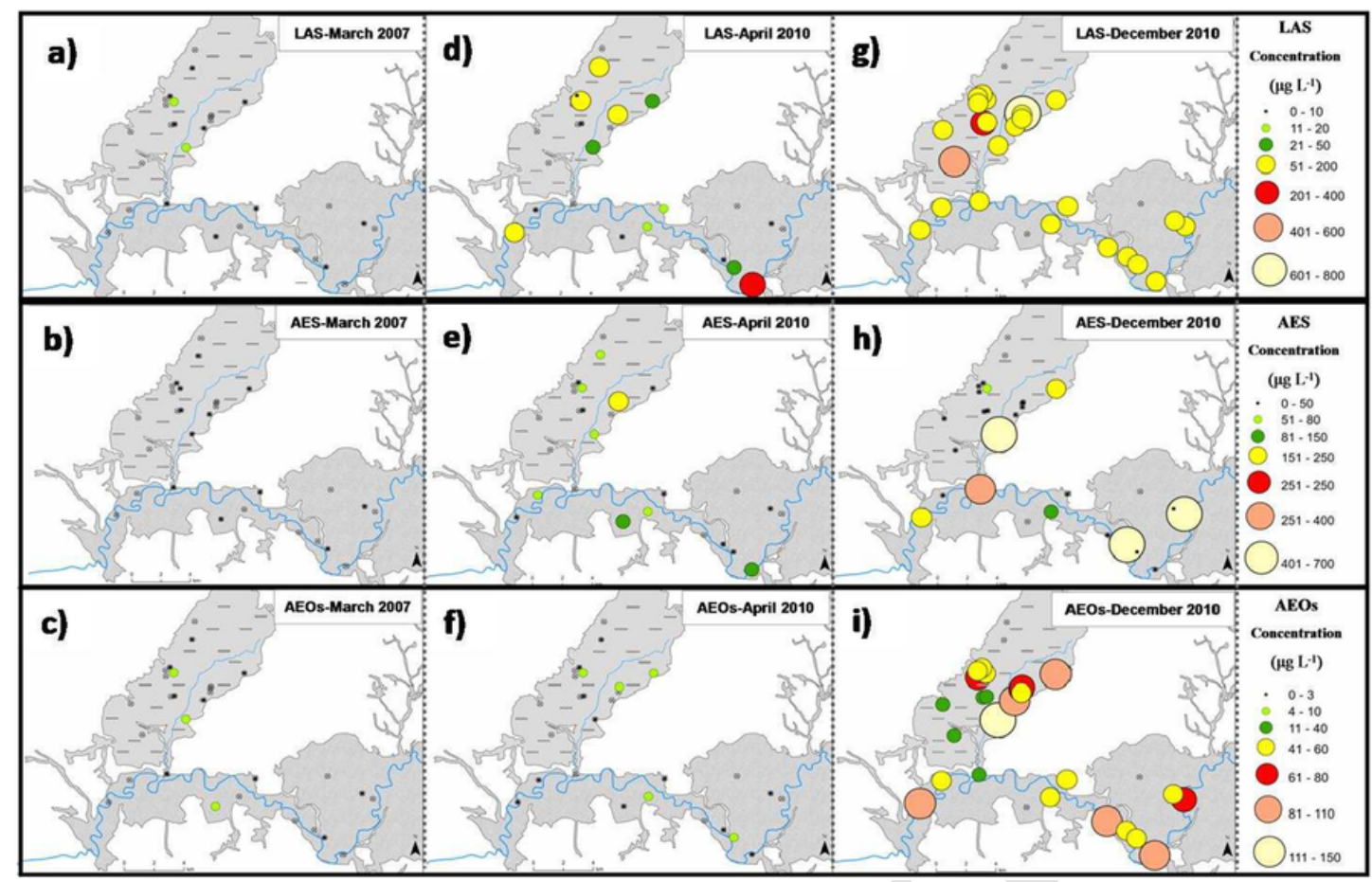

Fig. 5. Surfactants concentration (LAS, AES, AEOs) $\left(\mu \mathrm{g} \mathrm{L}{ }^{-1}\right)$ in groundwater. Results from March 2007, April 2010 and December 2010 sampling campaigns.

$139 \mu \mathrm{g} \mathrm{L}^{-1}$ for AEOs and $<1 \mu \mathrm{g} \mathrm{L^{-1 }}$ for NPEOs). As for anionic surfactants, the highest values $\left(>90 \mu \mathrm{g} \mathrm{L}^{-1}\right)$ are related to presence of untreated effluents $(\mathrm{J}-11, \mathrm{~J}-13$, and J-19) in the western part of the study area, or to urban settlements (G-26 and G-33). The nonylphenol (NP), a degradation product of NPEOs, previously reported in aquifers from Barcelona whose major source of recharge is a river receiving large amounts of effluents from WWTPs (Tubau et al., 2010) was not detected in this research.

Thus, presence of surfactants in groundwater was the combination of extreme rainfall events, shallow groundwater level and an aquifer rapidly responding to infiltrating water and leaching of compounds stored in the unsaturated zone of aquifers. Besides, the untreated wastewater effluents directly discharged into river or stream channels (also due to WWT plants overflow) in the hydraulically connected aquifers may also contribute.

In Table $4 \mathrm{a}$ and $\mathrm{b}$ results of selected PPCPs (e.g., analgesic, antibiotics, fragrances, UV filters) and regulated contaminants (including PAHs, PCBs, triazines several classes of pesticides and pyrethroids) in groundwater samples are presented for December 2010, the only sampling campaign available. 24 chemicals out of $>180$ were detected with concentrations of $<0.1 \mu \mathrm{g} \mathrm{L}^{-1}$. Regarding pesticides (Table 4a), the highest concentration found was for terbuthylazine (herbicide), $1860 \mathrm{ng} \mathrm{L}^{-1}$ (J-8) and lindane (insecticide) with $110 \mathrm{ng} \mathrm{L}^{-1}$ (G-26), this last compound banned in the EU in 2010. Thereby, the high concentration of terbuthylazine in the well J8 is likely due to uncontrolled dumping while the frequent occurrence of lindano, also applied as antiparasic under veterinary use, could be associated to its use on farms located in the study area. On the other hand, these compounds (Table 4a) were also detected at low concentrations in the Guadalete River, suggesting the hydraulic connection. The pesticides endosulfan, dieldrin and terbutryn, were occasionally found in groundwater samples at relatively low concentration $\left(<70 \mathrm{ng} \mathrm{L}^{-1}\right)$. In general, most pesticides were detected in water points where agricultural activities are predominant (e.g., J8, Fig. 1).
Data are in agreement with findings on the presence of pesticides of restricted use, such as chlorfenvinphos and chlorpyriphos, reported in the same wells (Perez-Carrera, 2009).

Most PPCPs (Tables 4a and b) were only found in Jerez de la Frontera aquifer, in wells heavily influenced by treated (e.g., WWTP) or untreated (e.g., Salado Stream) wastewater. A synthetic fragrance (OTNE) and a diuretic (hydrochlorothiazide) showed the highest concentrations (up to 1285 and $1025 \mathrm{ng} \mathrm{L}^{-1}$ ), followed by the sunscreen products benzophenone 3 and EHMC $\left(<500 \mathrm{ng} \mathrm{L}^{-1}\right)$. Observed PCPs values are significantly higher than those previously reported in groundwater samples from the Llobregat river aquifers (Barcelona, Spain) where BHT (an antioxidant) and galaxolide were found at $455 \mathrm{ng} \mathrm{L}^{-1}$ and $359 \mathrm{ng} \mathrm{L}^{-1}$, respectively (Teijon et al., 2010).

It is important to notice that there is a lack of information on the construction scheme and especially on the well screen location of most sampled points. In the Jerez water body, presence of one or two aquifer units may exist. Samples do not exclude the possibility of considering water from different aquifer levels if the well screen extends over the hole drilled wells. Variations of contaminant concentrations in close wells may be the result of quality stratification, borehole construction or variation in land use-land cover.

\section{Conclusions}

This study focuses in an important aspect of the EU planning approach (regarding water quality and changes and water directives) due to extreme events. The samplings campaigns here presented only refer to a specific period characterized by extreme events (extreme precipitation and impacts produced).

The work has discussed the presence and changes in the concentrations of the widely used surfactants (LAS, AES, AEOs and NPEOs) in the Guadalete River and groundwater from the alluvial and Jerez de la Frontera aquifers. Thus, the presence of surfactants is the result of agricultural, urban and industrial activities in the basin 


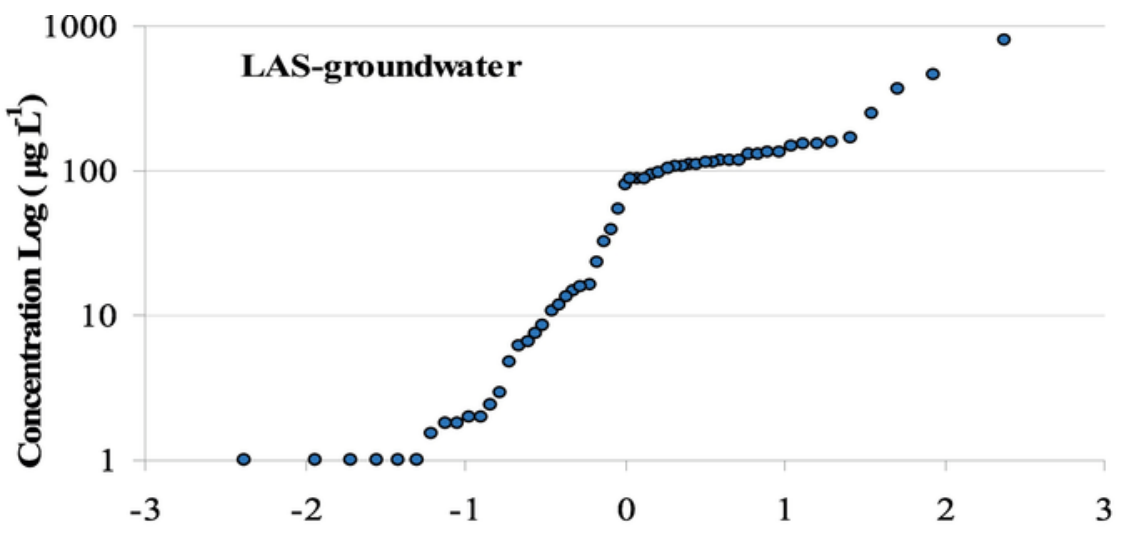

Theorical Quantiles

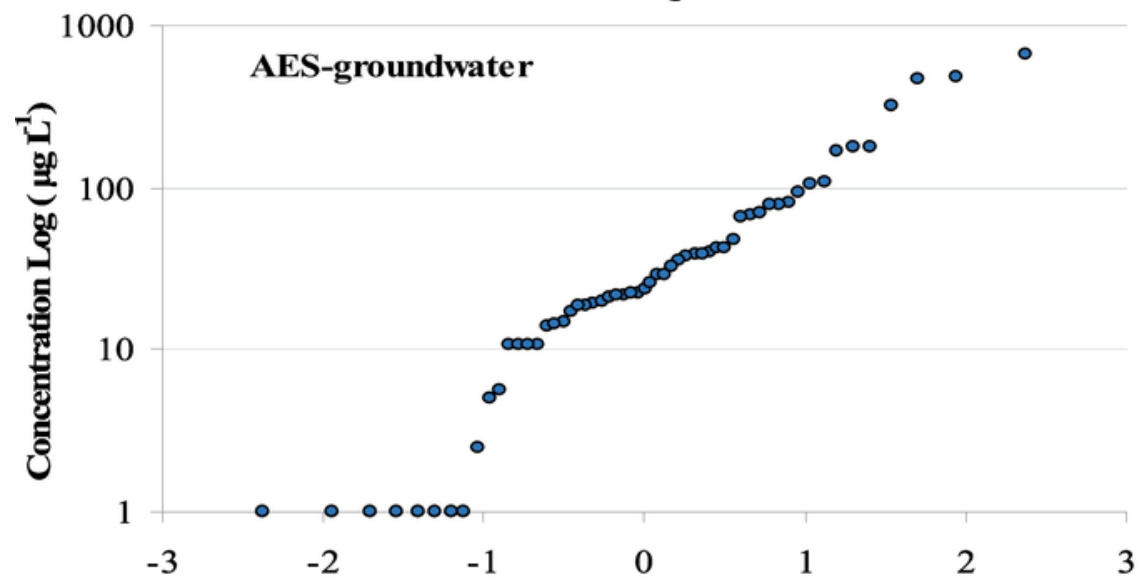

Theorical Quantiles

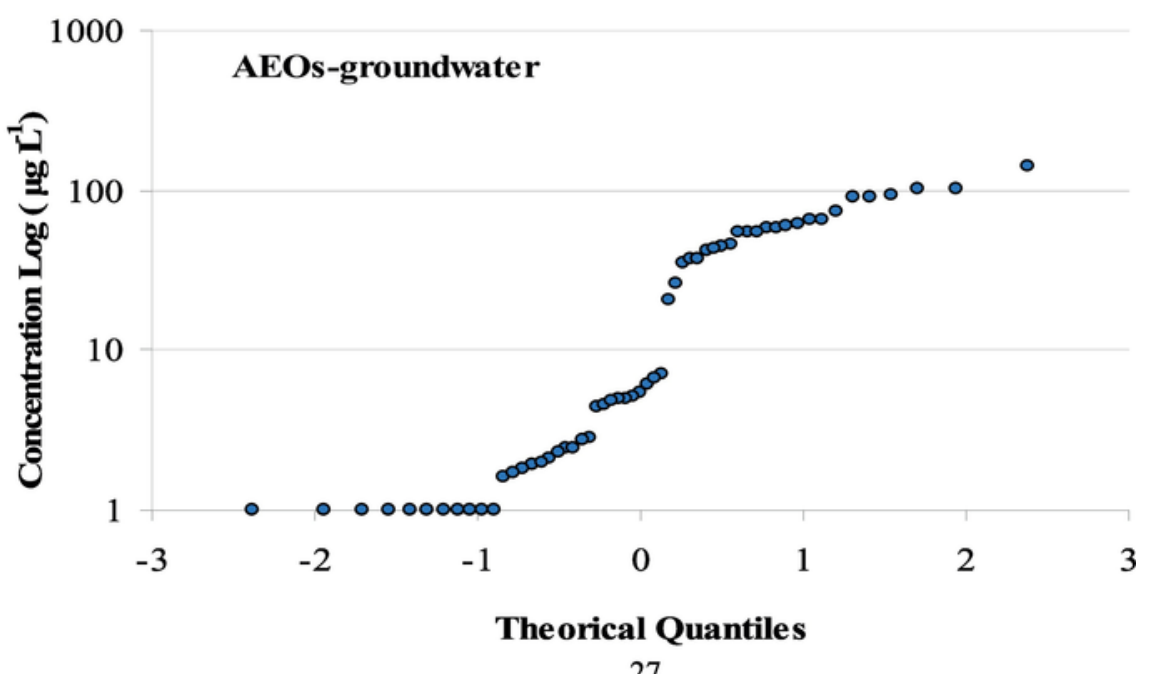

27

Fig. 6. Q-Q plots for LAS, AES and AEOs concentration in groundwater samples (2007 and 2010 campaigns).

jointly with extreme rainfall and seasonal changes in the water systems temperature, which promotes the degradation processes. Most of surfactants (LAS, AES and AEOs) were detected in all aqueous samples and their spatial distributions were related to the presence of local sewage sources in the basin. In addition, changes in their concentrations are clearly correlated with extreme rainfall events and consequently the effect of combined sewer overflow (CSO) that dis- charges a mix of rainwater runoff and untreated wastewater from domestic and industrial use directly into the river. Thus, a direct relationship was observed between the Guadalete River flow (or water height) as a consequence of the heavy rainfall (when CSO occurs) and the highest concentrations of surfactants in both surface and groundwater. In addition, high levels of these contaminants is not only the effects of combination of high rainfall event and untreated 
wastewater discharges in the river (CSO) but also the surface runoff losses, the hydraulic river-aquifer connection and the shallow aquifer. Thus, a determinant factor in the control pollution is the thickness of the unsaturated zone, increasing the risk in shallow aquifers.

On the other hand, surfactants sources could be identified with high specificity, they serve as excellent markers of sewage pollution and allowed to identify main urban origin of pollution, as it happened in the Guadalete River. We have also reported here, for the first time, the presence of aliphatic surfactants (AES and AEOs) in groundwater at similar or even higher concentrations to those found for aromatic surfactants (LAS and NPEOs).

Additional analytical effort was carried out in the last sampling campaigns (during heavy rainfall event), consisting on the determination of a wide variety of pharmaceutical and personal care products (PPCPs) as well as regulated compounds in both surface and groundwater samples. With respect to PPCPs, only 22 and 17 out of 126 compounds were measured in surface and groundwater respectively. Most of frequently detected compounds were fragrances (OTNE, galaxolide, tonalide), UV filters (benzophenone 3, EHMC) and analgesics anti-inflammatories (acetaminophen, salicylic acid, ibuprofen, naproxen, mefenamic acid). Probably, their presence is associated with urban untreated sewage sources into the river (CSO and Salado Stream) and the WWTP discharge outlet. Concerning priority compounds, 2 and 7 out of 72 compounds were measured in surface and groundwater respectively. The most detected compound was an ectoparasiticide (lindano), presumably associated to its veterinary use on farms located in the study area.

Regarding groundwater results, response is non-linear depending on hydraulic characteristics of aquifer, and delay of aquifer response (leaching) of contaminants stored in the vadose zone. Variation in land-use, land-cover and groundwater flow pattern should not be discarded.

Finally, descriptive statistics do not involve formal distribution hypothesis, however they provide a rapid view of the amount, range and quality of data as presented here. We applied descriptive statistics as an alternative to complement data analysis because sample sizes maybe insufficient for robust statistical analysis.

\section{Acknowledgements}

We express our gratitude to R.Gey-Flores and X.Bellés-Felip for his technical support, E. Pérez-Carrera for her help during the samplings. We are thankful to "Consejería de Medio Ambiente y Ordenación del Territorio - Junta de Andalucía" for hydrological data support. This research has been funded by the CICYT projects CGL2008-05598 and CGL2011-27349 and a FPI fellowship from the Spanish Ministry of Education and Science. Some financial support was also provided by other two regional research projects (RNM 5417 and RNM 6613) funded by Junta de Andalucía.

\section{Appendix A. Supplementary data}

Supplementary data to this article can be found online at http://dx. doi.org/10.1016/j.scitotenv.2017.06.049.

\section{References}

Baena-Nogueras, R.M., Pintado-Herrera, M.G., González-Mazo, E., Lara-Martín, P.A 2016. Determination of pharmaceuticals in coastal systemes using Solid Phase Extraction (SPE) followed by ultra performance liquid chromatography- tandem mass spectrometry (UPLC-MS/MS). Curr. Anal. Chem. 12, 1-19. http://dx.doi.org/10. 2174/1573411012666151009193254.

Belanger, S.E., Dorn, P.B., Toy, R., Boeije, G., Marshall, S.J., Wind, T., Van Compernolle, R., Zeller, D., 2006. Aquatic risk assessment of alcohol ethoxylates in
North America and Europe. Ecotoxicol. Environ. Saf. 64, 85-99. http://dx.doi.org/ 10.1016/j.ecoenv.2005.11.003.

Benotti, M.J., Brownawell, B.J., 2007. Distributions of pharmaceuticals in an urban estuary during both dry- and wet-weather conditions. Environ. Sci. Technol. 41, 5795-5802. http://dx.doi.org/10.1021/es0629965.

Bester, K., Klasmeier, J., Kupper, T., 2008. Emissions of OTNE (Iso-E-super) - mass flows in sewage treatment plants. Chemosphere 71, 2003-2010. http://dx.doi.org/ 10.1016/j.chemosphere.2008.02.004.

Boluda-Botella, N., León, V.M., Cases, V., Gomis, V., Prats, D., 2010. Fate of linear alkylbenzene sulfonate in agricultural soil columns during inflow of surfactant pulses. J. Hydrol. 395, 141-152. http://dx.doi.org/10.1016/j.jhydrol.2010.10.014

Buerge, I.J., Poiger, T., Müller, M.D., Buser, H.R., 2006. Combined sewer overflows to surface waters detected by the anthropogenic marker caffeine. Environ. Sci. Technol. 40, 4096-4102. http://dx.doi.org/10.1021/es0525531.

Cabeza, Y., Candela, L., Ronen, D., Teijon, G., 2012. Monitoring the occurrence of emerging contaminants in treated wastewater and groundwater between 2008 and 2010. The Baix Llobregat (Barcelona, Spain). J. Hazard. Mater. 239-240, 32-39. http://dx.doi.org/10.1016/j.jhazmat.2012.07.032.

Carballa, M., Omil, F., Lema, J.M., Llompart, M., García, C., Rodriguez, I., Gómez, M., Ternes, T., 2005. Behaviour of pharmaceuticals and personal care products in a sewage treatment plant of northwest Spain. Water Sci. Technol. 29-35.

Corada-Fernández, C., Lara-Martín, P.A., Candela, L., González-Mazo, E., 2011. Tracking sewage derived contamination in riverine settings by analysis of synthetic surfactants. J. Environ. Monit. 13, 2010-2017. http://dx.doi.org/10.1039/ c1em10150a.

Corada-Fernández, C., Lara-Martín, P.A., Candela, L., González-Mazo, E., 2013. Vertical distribution profiles and diagenetic fate of synthetic surfactants in marine and freshwater sediments. Sci. Total Environ. 461-462, 568-575. http://dx.doi.org/10. 1016/j.scitotenv.2013.04.100.

Corada-Fernández, C., Jiménez-Martínez, J., Candela, L., González-Mazo, E., Lara-Martín, P.A., 2015. Occurrence and spatial distribution of emerging contaminants in the unsaturated zone. Case study: Guadalete River basin (Cadiz, Spain). Chemosphere 119, S131-S137. http://dx.doi.org/10.1016/j.chemosphere.2014.04. 098 .

De Bustamante, I., Cabrera, M.C., Candela, L., Lillo, J., Palacios, M.P., 2010. La reutilización de aguas regeneradas en España: ejemplos de aplicación en el marco del proyecto CONSOLIDER-TRAGUA. Agua-LAC 2 (1), 1-17.

Del Río, H., Suárez, J., Puertas, J., Ures, P., 2013. PPCPs wet weather mobilization in a combined sewer in NW Spain. Sci. Total Environ. 449. http://dx.doi.org/10. 1016/j.scitotenv.2013.01.049

Directive 2013/39/EU. 2013. Del parlamento Europeo y del Consejo de 12 de agosto de 2013 por la que se modifican las Directivas 2000/60/CE Y 2008/105/CE en cuanto a las sustancias prioritarias en el ámbito de la política de aguas.

Dunphy, J.C., Pessler, D.G., Morrall, S.W., Evans, K.A., Robaugh, D.A., Fujimoto, G., Negahban, A., 2001. Derivatization LC/MS for the simultaneous determination of fatty alcohol and alcohol ethoxylate surfactants in water and wastewater samples. Environ. Sci. Technol. 35, 1223-1230. http://dx.doi.org/10.1021/es001491q.

Eadsforth, C.V., Sherren, A.J., Selby, M.A., Toy, R., Eckhoff, W.S., McAvoy, D.C., Matthijs, E., 2006. Monitoring of environmental fingerprints of alcohol ethoxylates in Europe and Canada. Ecotoxicol. Environ. Saf. 64, 14-29. http://dx.doi.org/ 10.1016/j.ecoenv.2005.06.009.

Ellis, J.B., 2006. Pharmaceutical and personal care products (PPCPs) in urban receiving waters. Environ. Pollut. 144, 184-189. http://dx.doi.org/10.1016/j.emcon.2016 12.004 .

EPA 530-R-09-007, March 2009. Statistical analysis of groundwater monitoring data at RCRA facilities. In: Unified Guidance. US Environmental Protection Agency, p. 884 .

Estévez, E., Cabrera, M.D.C., Molina-Díaz, A., Robles-Molina, J., Palacios-Díaz, M.D.P., 2012. Screening of emerging contaminants and priority substances (2008/ $105 / E C)$ in reclaimed water for irrigation and groundwater in a volcanic aquifer (Gran Canaria, Canary Islands, Spain). Sci. Total Environ. 433, 538-546. http://dx. doi.org/10.1016/j.scitotenv.2012.06.031.

Fendinger, N.J., Begley, W.M., McAvoy, D.C., Eckhoff, W.S., 1995. Measurement of alkyl ethoxylate surfactants in natural waters. Environ. Sci. Technol. 29, 856-863. http://dx.doi.org/10.1021/es00004a004.

García-Galán, M., Garrido, T., Fraile, J., Ginebreda, A., Díaz-Cruz, M.S., Barceló.D. 2010. Simultaneous occurrence of nitrates and sulfonamides antibiotics in two ground water bodies of Catalonia (Spain). J. Hydrol. 383, 93-101. http://dx.doi org/10.1016/j.jhydrol.2009.06.042.

Gasperi, J., Gromaire, M.C., Kafi, M., Moilleron, R., Chebbo, G., 2010. Contributions of wastewater, runoff and sewer deposit erosion to wet weather pollutant loads in combined sewer systems. Water Res. 44, 5875-5886. http://dx.doi.org/10.1016/j. watres.2010.07.008

González-Mazo, E., Forja, J.M., Gómez-Parra, A., 1998. Fate and distribution of linear alkylbenzene sulfonates in the littoral environment. Environ. Sci. Technol. 32, 1636-1641. http://dx.doi.org/10.1016/S0048-9697(01)00971-8. 
Haruvy, N., 2006. Reuse of wastewater in agriculture-economic assessment of treatment and supply alternatives as affecting aquifer pollution. In: Morel, B., Linkov, I. (Eds.), Environmental Security and Environmental Management: The Role of Risk Assessment. Springer, Netherlands, pp. 257-262.

Jobling, S., Sheahan, D., Osborne, J.A., Matthiessen, P., Sumpter, J.P., 1996. Inhibition of testicular growth in rainbow trout (Oncorhynchus mykiss) exposed to estrogenic alkylphenolic chemicals. Environ. Toxicol. Chem. 15, 194-202. http://dx. doi.org/10.1002/etc.5620150218.

Jurado, A., Vàzquez-Suñé, E., Carrera, J., López de Alda, M., Pujades, E., Barceló, D., 2012. Emerging organic contaminants in groundwater in Spain: a review of sources, recent occurrence and fate in a European context. Sci. Total Environ. 440, 82-94. http://dx.doi.org/10.1016/j.scitotenv.2012.08.029.

Kasprzyk-Hordern, B., Dinsdale, R.M., Guwy, A.J., 2009. The removal of pharmaceuticals, personal care products, endocrine disruptors and illicit drugs during wastewater treatment and its impact on the quality of receiving waters. Water Res. 43, 363-380. http://dx.doi.org/10.1016/j.watres.2008.10.047.

Kolpin, D.W., Furlong, E.T., Meyer, M.T., Thurman, E.M., Zaugg, S.D., Barber, L.B., Buxton, H.T., 2002. Pharmaceuticals, hormones, and other organic wastewater contaminants in U.S. streams, 1999-2000: a national reconnaissance. Environ. Sci. Technol. 36, 1202-1211. http://dx.doi.org/10.1021/es011055j.

Krueger, C.J., Barber, L.B., Metge, D.W., Field, J.A., 1998. Fate and transport of linear alkylbenzenesulfonate in a sewage-contaminated aquifer: a comparison of natural-gradient pulsed tracer tests. Environ. Sci. Technol. 32, 1134-1142. http://dx. doi.org/10.1021/es970717v.

Lapworth, D.J., Baran, N., Stuart, M.E., Ward, R.S., 2012. Emerging contaminants: a review of occurrence, sources and fate un groundwater. Environ. Pollut. 163, 287-303. http://dx.doi.org/10.1016/j.envpol.2011.12.034.

Lara-Martín, P.A., Gómez-Parra, A., González-Mazo, E., 2005. Determination and distribution of alkyl ethoxysulfates and linear alkylbenzene sulfonates in coastal marine sediments from the bay of Cadiz (southwest of Spain). Environ. Toxicol. Chem. 24, 2196-2202. http://dx.doi.org/10.1897/04-446R.1.

Lara-Martín, P.A., Gómez-Parra, A., González-Mazo, E., 2006. Development of a method for the simultaneous analysis of anionic and non-ionic surfactants and their carboxylated metabolites in environmental samples by mixed-mode liquid chromatography-mass spectrometry. J. Chromatogr. A 1137, 188-197. http://dx.doi. org/10.1016/j.chroma.2006.10.009.

Lara-Martín, P.A., Gómez-Parra, A., González-Mazo, E., 2008. Sources, transport and reactivity of anionic and non-ionic surfactants in several aquatic ecosystems in SW Spain: a comparative study. Environ. Pollut. 156, 36-45. http://dx.doi.org/10.1016/ j.envpol.2008.01.005

Lara-Martín, P.A., Corada-Fernández, C., Gómez-Parra, A., González-Mazo, E., 2010. Seasonal changes in the concentration of anionic surfactants in estuarine sediments from the River Guadalete (Cadiz, Spain). Sci. Mar. 74, 125-131. http://dx.doi.org/ 10.3989/scimar.2010.74s1125

León, V.M., Álvarez, B., Cobollo, M.A., Muñoz, S., Valor, I., 2003. Analysis of 35 priority semivolatile compounds in water by stir bar sorptive extraction-thermal desorption-gas chromatography-mass spectrometry: I. Method optimisation. J. Chromatogr. A 999, 91-101. http://dx.doi.org/10.1016/S0021-9673(03)00600-9.

León, V.M., Gómez-Parra, A., González-Mazo, E., 2004. Biodegradation of linear Alkylbenzene sulfonates and their degradation intermediates in seawater. Environ. Sci. Technol. 38, 2359-2367. http://dx.doi.org/10.1021/es034813.

López, B., Ollivier, P., Togola, A., Baran, N., Ghestem, J.P., 2015. Screening of French groundwater for regulated and emerging contaminants. Sci. Total Environ. 518-519, 562-573. http://dx.doi.org/10.1016/j.scitotenv.2015.01.11.

Meffe, R., De Bustamante, I., 2014. Emerging organic contaminats in surface water and groundwater: a first overview of the situation in Italy. Sci. Total Environ. 481, 280-295. http://dx.doi.org/10.1016/j.scitotenv.2014.02.053.

Miège, C., Choubert, J.M., Ribeiro, L., Eusèbe, M., Coquery, M., 2009. Fate of pharmaceuticals and personal care products in wastewater treatment plants - conception of a database and first results. Environ. Pollut. 157, 1721-1726. http://dx.doi. org/10.1016/j.envpol.2008.11.045.

Oliver-Rodríguez, B., Zafra-Gómez, A., Reis, M.S., Duarte, B.P.M., Verge, C., de Ferrer, J.A., Pérez-Pascual, M., Vílchez, J.L., 2015. Evaluation of linear alkylbenzene sulfonate (LAS) behaviour in agricultural soil through laboratory continuous studies. Chemosphere 131, 1-8. http://dx.doi.org/10.1016/j.chemosphere.2015.02.037.

Oppel, J., Broll, G., Loffler, D., Meller, M., Rombke, J., Ternes, T., 2004. Leaching behaviour of pharmaceuticals in soils-testing-systems: a part of an environmental risk assessment for groundwater protection. Sci. Total Environ. 328, 265-273. http://dx.doi.org/10.1016/j.scitotenv.2004.02.004.

Ou, Z., Jia, L., Jin, H., Yediler, A., Jiang, X., Kettrup, A., Sun, T., 1999. Formation of soil macropores and preferential migration of linear alkylbenzene sulfonate (LAS) in soils. Chemosphere 38, 1985-1996. http://dx.doi.org/10.1016/ S0045-6535(98)00411-1.

Pedrouzo, M., Borrull, F., Marcé, R.M., Pocurull, E., 2011. Analytical methods for personal-care products in environmental waters. TrAC Trends Anal. Chem. 30, 749-760. http://dx.doi.org/10.1016/j.trac.2011.01.009.

Perez-Carrera, E., 2009. Distribution and Reactivity of Regulated and Emerging Organic Pollutants in Surface and Groundwater Systems. Physical-Chemistry Department. University of Cadiz, Cadiz. PhD.

Pérez-Carrera, E., Hansen, M., León, V.M., Björklund, E., Krogh, K.A., Halling-Sørensen, B., González-Mazo, E., 2010. Multiresidue method for the determination of 32 human and veterinary pharmaceuticals in soil and sediment by pressurized-liquid extraction and LC-MS/MS. Anal. Bioanal. Chem. 398, 1173-1184. http://dx.doi.org/10.1007/s00216-010-3862-x.

Petrovic, M., Fernández-Alba, A.R., Borrull, F., Marce, R.M., Mazo, E.G., Barceló, D., 2002. Occurrence and distribution of nonionic surfactants, their degradation products, and linear alkylbenzene sulfonates in coastal waters and sediments in Spain. Environ. Toxicol. Chem. 21, 37-46. http://dx.doi.org/10.1002/etc. 5620210106

Pintado-Herrera, M.G., González-Mazo, E., Lara-Martín, P.A., 2014. Environmentally friendly analysis of emerging contaminants by pressurized hot water extraction-stir bar sorptive extraction-derivatization and gas chromatography-mass spectrometry. Anal. Bioanal. Chem. 405, 401-411. http://dx.doi.org/10.1007/ s00216-012-6453-1.

Plan Hidrológico. Demarcación Hidrográfica del Guadalete-Barbate. (n.d.) Ciclo de Planificación Hidrológica 2015/2021. Consejería de Medio Ambiente y Ordenación del Territorio. Junta de Andalucía.

R Core Team, 2016. R: A Language and Environment for Statistical Computing. R Foundation for Statistical Computing, Vienna, Austria. https://www.R-project.org/.

Sanderson, H., Dyer, S.D., Price, B.B., Nielsen, A.M., van Compernolle, R., Selby, M., Stanton, K., Evans, A., Ciarlo, M., Sedlak, R., 2006. Occurrence and weight-of-evidence risk assessment of alkyl sulfates, alkyl ethoxysulfates, and linear alkylbenzene sulfonates (LAS) in river water and sediments. Sci. Total Environ. 368, 695-712. http://dx.doi.org/10.1016/j.scitotenv.2006.04.030.

State Meteorological Agency (AEMET), In: http://www.chguadalquivir.es/saih/ DatosHistoricos.aspx.

Stuart, M., Lapworth, D., Crane, E., Hart, A., 2012. Review of risk from potential emerging contaminants in UK groundwater. Sci. Total Environ. 416, 1-21. http:// dx.doi.org/10.1016/j.scitotenv.2011.11.072.

Teijon, G., Candela, L., Tamoh, K., Molina-Díaz, A., Fernández-Alba, A.R., 2010. Occurrence of emerging contaminants, priority substances (2008/105/CE) and heavy metals in treated wastewater and groundwater at Depurbaix facility (Barcelona, Spain). Sci. Total Environ. 408, 3584-3595. http://dx.doi.org/10.1016/j.scitotenv. 2010.04.041.

The European Parliament and the council of the European Union, 2013. Directive 2013/39/EU of the European Parliament and of the council of 12 August 2013 amending Directives 2000/60/EC and 2008/105/EC as regards priority substances in the field of water policy. Off. J. Eur. Union 1-17.

Tubau, I., Vázquez-Suñé, E., Carrera, J., González, S., Petrovic, M., López de Alda, M.J., Barceló, D., 2010. Occurrence and fate of alkylphenol polyethoxylate degradation products and linear alkylbenzene sulfonate surfactants in urban ground water: Barcelona case study. J. Hydrol. 383, 102-110. http://dx.doi.org/10.1016/j. jhydrol.2009.11.030.

U.S. Environmental Protection Agency (EPA), Washington, D.C. 2004."Report to Congress: Impacts and Control of CSOs and SSOs.” August 2004. Document No. EPA-833-R-04-001.

Valdes-Abellan, J., Candela, L., Jiménez-Martínez, J., Saval-Pérez, J.M., 2013. Brackish groundwater desalination by reverse osmosis in southeastern Spain. Presence of emerging contaminants and potential impacts on soil-aquifer media. Desalin. Water Treat. 51, 2431-2444. http://dx.doi.org/10.1080/19443994.2012.747506.

Xu, J., Chen, W., Wu, L., Green, R., Chang, A.C., 2009. Leachability of some emerging contaminants in reclaimed municipal wastewater-irrigated turf grass field. Environ. Toxicol. Chem. 28, 1842-1850. http://dx.doi.org/10.1897/08-471.1. 